\title{
ACE-inhibitory activity and ACE-inhibiting peptides in different cheese varieties
}

\author{
Robert Sieber, Ueli Bütikofer, Charlotte Egger, Reto Portmann, \\ Barbara Walther, Daniel WeChSLER*
}

Agroscope Liebefeld-Posieux Research Station ALP, 3003 Berne, Switzerland

Received 27 April 2009 - Revised 28 October 2009 - Accepted 29 October 2009

Published online 17 December 2009

\begin{abstract}
During the ripening of cheese, a large number of peptides are formed from casein. Some of these peptides have been shown to exert an antihypertensive effect due to their angiotensin-I-converting enzyme (ACE)-inhibitory activity. Recently, several studies have investigated the ACE-inhibiting potential of cheese, and various ACE-inhibiting peptides have been isolated and identified from different cheese varieties. The present review focuses on the occurrence of two tripeptides, Val-Pro-Pro and Ile-Pro-Pro, in cheese. These tripeptides were first described in fermented-milk products and have been demonstrated to exert a blood pressure-lowering effect in humans with mild hypertension. The influence of cheesemaking and ripening on the release of ACE-inhibiting peptides is revealed. Finally, the antihypertensive potential of cheese with high ACE-inhibitory activity is discussed with regard to the bioavailability of the peptides involved.
\end{abstract}

ACE-inhibitory activity / ACE-inhibiting peptide / tripeptide / VPP / IPP / cheese / cheese ripening

摘要 - 不同干酪品种的 ACE 抑制活性与 ACE 抑制肽。干酪成熟过程中, 酪蛋白被分解成 大量的蛋白肽。其中有的已被证明具有降血压的功能, 因为它们有血管紧张素-I-转换酶 (ACE) 抑制活性。最近, 有研究发现了干酪的 ACE 抑制活性, 并从不同品种的干酪中分离得到 了各种 ACE 抑制肽。本文主要讨论了干酪中的两个三肽 Val-Pro-Pro (VPP) 和 Ile-Pro-Pro (IPP) 的产生, 他们首次在发酵乳制品中被发现, 而且证实了对轻度高血压人群具有降低血压的 功能。同时, 综述了干酪加工与成熟过程对 ACE 抑制肽产生的影响。最后, 应用肽的 生物利用度讨论了高 ACE 抑制活性干酪的降压能力。

\section{ACE 抑制活性 / ACE 抑制肽 / 三肽 / VPP / IPP / 干酪 / 干酪成熟}

Résumé - Activité inhibitrice et peptides inhibiteurs de l'ACE dans différentes sortes de fromage. Au cours de la maturation du fromage, un grand nombre de peptides sont formés à partir de la caséine. Quelques-uns d'entre eux sont réputés exercer des effets antihypertenseurs en raison de l'activité inhibitrice de l'enzyme de conversion de l'angiotensine I (ACE). Récemment, plusieurs études ont examiné le potentiel inhibiteur d'ACE du fromage, et divers peptides inhibiteurs de l'ACE ont été isolés de différentes sortes de fromage puis identifiés. La présente revue porte sur la présence de deux tripeptides Val-Pro-Pro (VPP) et Ile-Pro-Pro (IPP) dans le fromage. Ces tripeptides sont parmi les premiers à avoir été décrits dans les produits laitiers fermentés et sont réputés

*Corresponding author: daniel.wechsler@alp.admin.ch 
exercer un effet antihypertenseur chez les patients présentant une légère hypertension. Cette revue porte aussi sur l'influence de la fabrication et de l'affinage du fromage sur la libération des peptides inhibiteurs de l'ACE, sur le potentiel antihypertenseur du fromage avec une activité inhibitrice élevée de l'ACE de même que la biodisponibilité des peptides en question.

activité inhibitrice de l'ACE / peptide inhibiteur de l'ACE / tripeptide / VPP / IPP / fromage / affinage de fromage

\section{INTRODUCTION}

Due to its composition, cheese is of major significance in human nutrition [114]. During ripening, cheese is exposed to various enzymatic processes, mainly driven by specialized bacteria that contribute to the characteristic flavour of each variety. The ripening process of different cheese varieties of Swiss origin, such as Emmental [7, 8], Gruyère [120], Sbrinz [119], Appenzell [121], Tilsit [122] and Raclette [108], has been investigated in detail. Proteolysis is the principal event of cheese ripening and starts with the initial breakdown of the caseins through the action of coagulants and indigenous proteinases in milk. Through the action of bacterial proteases and peptidases during secondary proteolysis, a large number of peptides of variable chain length are released from the protein [99]. In Emmental, for example, in a Swiss study [14] more than 100 and in a French study [28] 91 watersoluble peptides were found in cheeses aged 4, 13, 36 and $50 \mathrm{~d}$; similarly, a total of 107 peptides were identified in protein fractions of artisanal or industrial Manchego cheese after 4 and 8 months of ripening [34].

Recently, it has been recognized that various specific peptides that are released by digestive enzymes or that are present in fermented foods may exert beneficial effects in vivo. Cheese and milk products have been found to be a rich source of so-called bioactive peptides $[36,75]$. Depending on their functionality, bioactive peptides are divided into various groups, such as casomorphins, angiotensin-converting enzyme
(ACE $=$ dipeptidyl carboxypeptidase; EC 3.4.15.1)-inhibiting peptides, phosphopeptides, immunopeptides, casoplatelins (with antithrombotic effects) and antimicrobial and cytomodulating peptides [9, 50]. Due to their hypotensive effect, ACE-inhibitory peptides are of special interest, as hypertension is a major risk factor for both coronary heart disease and stroke, and represents an increasing health problem in Western countries. Different medical drugs, including ACE inhibitors, antagonists of angiotensin II type 1 receptors, betablockers, calcium antagonists and diuretics, have been developed for the treatment of hypertension. According to Nussberger [83], more than 40 million patients are treated worldwide with ACE-inhibiting drugs, such as Captopril or Enalapril, that are structurally related to the ACE-inhibiting peptides present in snake venom $[18,29]$. Smaller reductions in average blood pressure may be obtained by nutritional measures, such as reducing sodium intake or increasing daily consumption of ACE-inhibitory peptides. The results of a large meta-analysis indicate that even a $2 \mathrm{~mm} \mathrm{Hg}$-lower usual SBP would involve about $10 \%$ lower stroke mortality and about 7\% lower mortality from ischaemic heart disease in middle age [96].

$\mathrm{ACE}$ is part of the rennin-angiotensin system that regulates peripheral blood pressure. It catalyses the conversion of angiotensin I into the potent vasoconstrictor angiotensin II and, simultaneously, the degradation of bradykinin, a vasodilatory nonapeptide. These two reactions cause a contraction of the blood vessels and 
a consequent increase in blood pressure. ACE-inhibiting drugs prevent both the conversion of angiotensin I and the degradation of bradykinin, and thus induce an antihypertensive effect [53]. Apart from drugs and snake venom, several dietary peptides, as well as other food components, such as calcium [63], $\gamma$-aminobutyric acid [39], exopolysaccharides from Lactobacillus $[L$. $]$ casei [2], polyphenols in cocoa and tea [124] and nitrate from vegetables [135] or a diet rich in fruits, vegetables and low-fat dairy products [5], have been reported to be effective in lowering blood pressure. Using in vitro or in vivo experiments, ACEinhibiting activity has been found in a large number of products, such as fermented milk $[27,42,49,52,76,79,80,109,138]$, hydrolysed food proteins [53], soya [54], zein [71, 141], corn gluten meal [140], sorghum [45], potatoes [58, 91], sesame [81], peanuts [98], algae [112], eggs [67, 68, 97], beef hydrolysates [40], porcine skeletal muscle [46, 47], chicken breast muscle [104], chicken collagen hydrolysate [103], fish $[20,60]$, sardine muscle [61], oysters [134], haemoglobin [70], royal jelly [62], coffee [101] and wine [93].

\section{ACE-INHIBITORY ACTIVITY IN CHEESE}

\subsection{Determination of ACE- inhibitory activity in cheeses}

Cushman and Cheung [21] developed an in vitro assay for the determination of ACE inhibition using hippuryl-histidyl-leucyl$\mathrm{OH}$ (HHL) as a substrate. Incubation with ACE leads to the formation of hippuric acid that can be measured at $228 \mathrm{~nm}$ in a spectrophotometer. Parrot et al. [90] used a modified method for the investigation of ACE-inhibitory peptides in Emmental cheese. In this assay, ACE-inhibitory activity is measured in the presence of a watersoluble cheese extract, and inhibition of
ACE is expressed as percentage of reduction in the ACE-inhibitory activity as compared to the blank sample. Additionally, the determination of the half-maximal inhibitory concentration $\left(\mathrm{IC}_{50}\right)$ of individual peptides and drugs allows a direct comparison of their ACE-inhibitory potential. An alternative and faster method for testing the ACE-inhibitory activity of peptides uses furanacryloylphenylalanyl-glycyl-glycine (FAPGG) as the substrate. ACE hydrolyses this substrate to the corresponding amino acids FA-Phe and the dipeptide Gly-Gly, and the rate of decrease of absorbance is measured at $340 \mathrm{~nm}$ [133]. Shalaby et al. [111] compared the in vitro assays using HHL and FAPGG as substrates. Although a similar relative standard deviation between replicate samples of around $7 \%$ was obtained for both methods, the results of the two assays did not correlate for all samples. This discrepancy underlines the importance of good control of the ACE-inhibitory activity in the assay and the use of reference substances, such as Captopril, with known blood pressure-lowering effects.

Okamoto et al. [85] measured the ACEinhibitory activity in various fermented foods, such as fish sauce, sake, soy sauce, vinegar and cheese. Among all investigated foods, the highest activity was obtained in Camembert and Red Cheddar, which was explained by the presence of casein-derived peptides. However, lower activity was found in Blue cheese and none in Cottage cheese (Tab. I). In several other studies, similar in vitro experiments were performed using the water-soluble extracts of other cheese varieties, such as Harz, Camembert, Roquefort, Tilsit, Gouda, Edam, Leerdam, Emmental and Parmesan [64]; Italian cheeses of short and medium ripening time, including Mozzarella, Italico, Crescenza and Gorgonzola [118]; Gouda, Emmental, Blue, Camembert, Edam and Havarti [105]; Norvegia, Jarlsberg, Cheddar and Blue [123]; Cheddar, Feta, Roquefort and English hard cheese [4]; Spanish cheese 
Table I. Determination of the ACE-inhibitory activity in various cheese varieties.

\begin{tabular}{|c|c|c|c|c|}
\hline \multirow[t]{2}{*}{ Cheese } & \multicolumn{3}{|c|}{ ACE-inhibitory activity } & \multirow[t]{2}{*}{$\overline{\text { Reference }}$} \\
\hline & $\begin{array}{c}\mathrm{IC}_{50} \\
\left(\mathrm{mg} \cdot \mathrm{mL}^{-1}\right) \\
\end{array}$ & $\begin{array}{l}\text { WSE } \\
(\%)\end{array}$ & $\begin{array}{c}\mathrm{WSE}<1000 \mathrm{~g} \cdot \mathrm{mol}^{-1} \\
(\%)\end{array}$ & \\
\hline Mozzarella & & 59 & & [118] \\
\hline Italico & & 82 & & [118] \\
\hline Crescenza & & 37 & & [118] \\
\hline Gorgonzola & & 80 & & [118] \\
\hline Red Cheddar & 0.16 & & & {$[85]$} \\
\hline Camembert & 0.16 & & & [85] \\
\hline Blue & 0.27 & & & [85] \\
\hline Cottage & Not detected & & & [85] \\
\hline Gouda (8 months) & & 75.5 & & [105] \\
\hline Gouda (24 months) & & 78.2 & & [105] \\
\hline Emmental & & 48.8 & & [105] \\
\hline Blue & & 49.9 & & [105] \\
\hline Camembert & & 69.1 & & [105] \\
\hline Edam & & 56.2 & & [105] \\
\hline Havarti & & 72.7 & & [105] \\
\hline Norvegia & & 61.7 & & {$[123]$} \\
\hline Jarlsberg & & 41.7 & & [123] \\
\hline Cheddar & & 66.0 & & [123] \\
\hline Blue & & 39.3 & & [123] \\
\hline Emmental & $27.6 \pm 8.4^{\mathrm{a}}$ & & & {$[90]$} \\
\hline Idiazabal & & $87.5 \pm 2.5$ & $68.5 \pm 2.4$ & {$[35]$} \\
\hline Manchego & & $70.6 \pm 1.5$ & $65.3 \pm 2.0$ & [35] \\
\hline Roncal & & $85.8 \pm 0.5$ & $70.4 \pm 1.9$ & [35] \\
\hline Mahon & & $76.8 \pm 5.6$ & $56.6 \pm 4.6$ & [35] \\
\hline Goat cheese & & $72.8 \pm 7.7$ & $59.4 \pm 4.6$ & [35] \\
\hline Cabrales & & $74.7 \pm 2.1$ & $76.1 \pm 1.5$ & [35] \\
\hline Gamalost & $1.0 \pm 0.2^{\mathrm{b}}$ & $0.61 \pm 0.14^{\mathrm{c}}$ & & [95] \\
\hline Castello & $1.1 \pm 0.2^{\mathrm{b}}$ & $0.12 \pm 0.03^{\mathrm{c}}$ & & [95] \\
\hline Brie & $1.3 \pm 0.3^{\mathrm{b}}$ & $0.11 \pm 0.01^{\mathrm{c}}$ & & [95] \\
\hline Pultost & $1.3 \pm 0.5^{\mathrm{b}}$ & $0.17 \pm 0.07^{\mathrm{c}}$ & & [95] \\
\hline Port Salut & $1.4 \pm 0.1^{\mathrm{b}}$ & $0.09 \pm 0.01^{\mathrm{c}}$ & & [95] \\
\hline Norvegia (3 months) & $1.6 \pm 0.2^{\mathrm{b}}$ & $0.08 \pm 0.01^{\mathrm{c}}$ & & [95] \\
\hline Norvegia (9 months) & $1.7 \pm 0.6^{\mathrm{b}}$ & $0.09 \pm 0.03^{\mathrm{c}}$ & & [95] \\
\hline Kesam & $7.7 \pm 1.4^{\mathrm{b}}$ & $0.01 \pm 0.003^{\mathrm{c}}$ & & [95] \\
\hline Traditional cheeses $(n=44)$ & $2.0-29.5^{\mathrm{a}}$ & & & {$[16]$} \\
\hline $\begin{array}{l}\text { Herb- and fruit-enriched cheeses } \\
(n=8)\end{array}$ & & & $25-74$ & {$[4]$} \\
\hline Cheddar probiotic (36 weeks) & & & & [86] \\
\hline Control & 0.37 & $\approx 80$ & & [86] \\
\hline L. casei 279 & 0.23 & $\approx 82$ & & [86] \\
\hline L. casei LAFTI $^{\circledR}$ L26 & 0.25 & $\approx 82$ & & {$[86]$} \\
\hline
\end{tabular}


Table I. Continued.

\begin{tabular}{|c|c|c|c|c|}
\hline \multirow[t]{2}{*}{ Cheese } & \multicolumn{3}{|c|}{ ACE-inhibitory activity } & \multirow[t]{2}{*}{ Reference } \\
\hline & $\begin{array}{c}\mathrm{IC}_{50} \\
\left(\mathrm{mg} \cdot \mathrm{mL}^{-1}\right)\end{array}$ & $\begin{array}{l}\text { WSE } \\
(\%)\end{array}$ & $\begin{array}{c}\mathrm{WSE}<1000 \mathrm{~g} \cdot \mathrm{mol}^{-1} \\
(\%)\end{array}$ & \\
\hline $\begin{array}{l}\text { Cheddar with different } \\
\text { starter bacteria }\end{array}$ & $\begin{array}{c}0.28 \text { (control), } \\
0.13-0.19\end{array}$ & & & [88] \\
\hline
\end{tabular}

varieties [35]; as well as various cheese varieties of Swiss origin [16]. Further investigations on water-soluble cheese extracts were carried out with probiotic cheeses, such as Festivo (a ripened low-fat cheese containing a total of 12 different strains of Lactococcus [Lc.] sp., Leuconostoc sp., Propionibacterium sp., Lactobacillus sp., and L. acidophilus and Bifidobacterium [B.] sp.) [102]; Cheddar with the addition of probiotic L. casei 279 or LAFTI ${ }^{\circledR}$ L26 [86]; and Cheddar manufactured with starter lactococci (Lc. lactis ssp. lactis, Leuconostoc lactis ssp. cremoris), B. longum 1941, B. animalis ssp. lactis LAFTI $^{\circledR}$ B94, L. casei 279 and L. acidophilus 4962 or LAFTI $^{\circledR}$ L10 [88]. Similarly, Pripp et al. [95] investigated the ACE-inhibitory potential of ethanol-soluble fractions of Gamalost, Pultost, Norvegia, Castello, French Brie, Port Salut and Kesam cheeses. Table I contains a summary of the results obtained from studies with cheese using in vitro experiments to determine ACE-inhibiting potential. Due to methodological differences and the lack of common reference substances, inter-study comparisons of the ACE-inhibitory activity of individual cheese varieties should be avoided. However, the results of several studies indicate that large variations exist in the ACE-inhibitory potential of different cheeses and that in vitro experiments are a helpful tool to identify cheese samples with high ACEinhibiting activity.

\subsection{ACE-inhibitory activity during cheese ripening}

Several studies investigated ACE-inhibitory activity during cheese ripening. In a study including young, medium-aged and mature Gouda, the strongest ACE-inhibitory activity was found in the medium-aged Gouda [64]. In contrast to this, Saito et al. [105] reported a slightly higher ACE inhibition in Gouda aged 24 months (78.2\%) than in 8-month-old Gouda (75.5\%). In Festivo cheese, ACE inhibition reached a value of $10 \%$ after 6 weeks of ripening, increased to $50 \%$ at week 13 and decreased to roughly $30 \%$ after 20 weeks [102]. The ACE-inhibitory activity of control and probiotic Cheddar cheeses (L. casei 279 and L. casei L26) increased in the first 24 weeks of ripening and remained rather stable in the subsequent 12 weeks. The $\mathrm{IC}_{50}$ value of the control cheese at 24 weeks was significantly higher than those of the probiotic cheeses. However, after 36 weeks of ripening, it was not significantly different [86]. In Cheddar cheeses produced with different probiotic strains, the ACE-inhibitory activity increased mainly during the first six weeks and was influenced significantly by ripening temperature, showing more increase at $8{ }^{\circ} \mathrm{C}$ than at $4{ }^{\circ} \mathrm{C}$ [88]. A further study [87] investigated the ACE-inhibitory activity during ripening of Cheddar cheese manufactured with three different combinations of cultures 
R. Sieber et al.

\section{Bernese Hobelkäse}

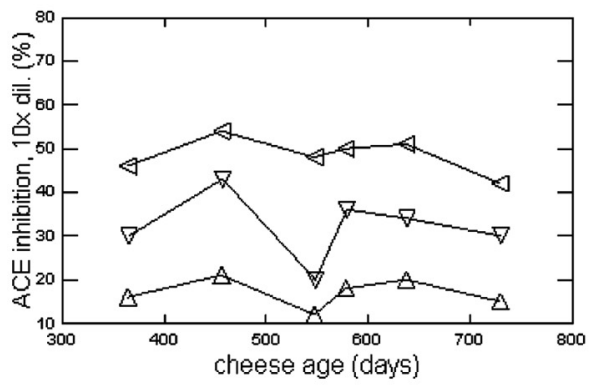

Emmental

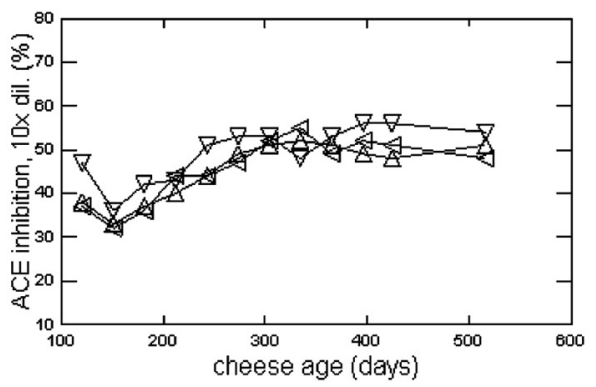

Appenzell $1 / 4$ fat

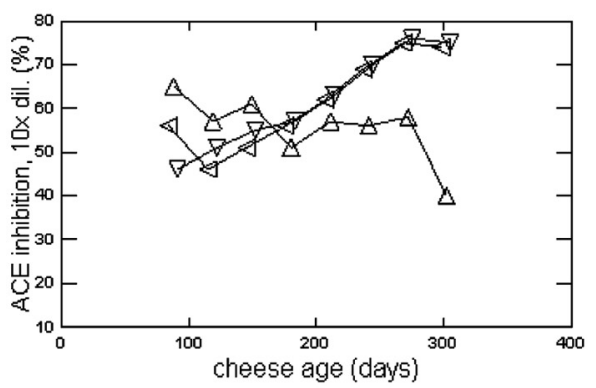

Tête de Moine

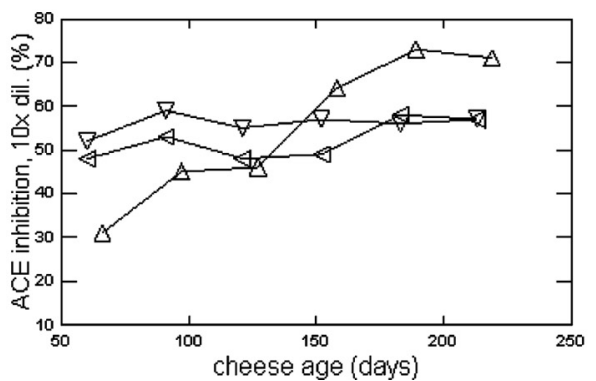

Gruyère

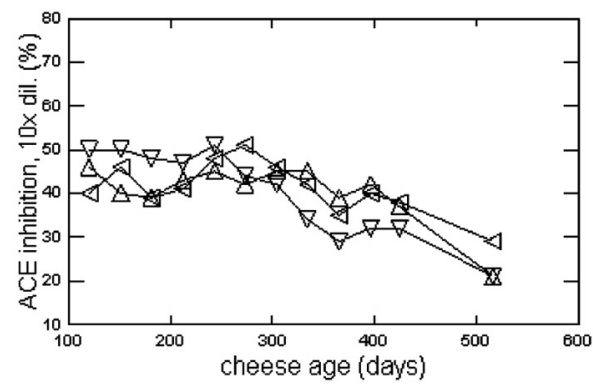

Tilsit

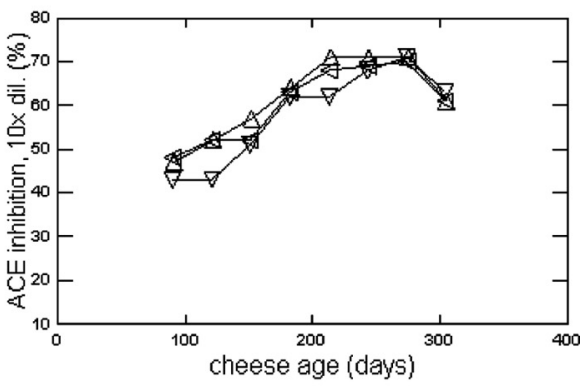

Vacherin fribourgeois

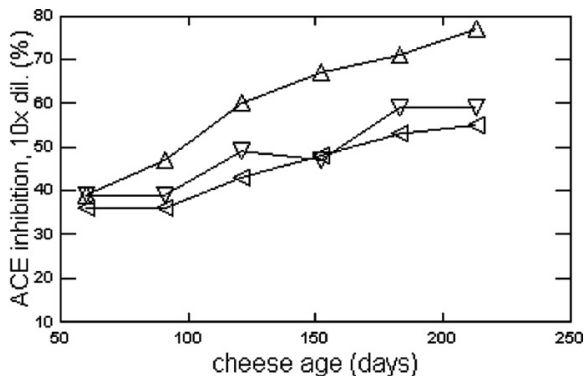

Figure 1. Development of ACE-inhibitory activity during ripening of extra-hard, hard and semihard cheeses of Swiss origin [66]. 
and ripened at temperatures of 4,8 and $12{ }^{\circ} \mathrm{C}$ over a period of 24 weeks. Control cheeses were made with starter lactococci; cheeses L10 with starter lactococci and L. acidophilus L10; and cheeses H100 with starter lactococci, L. acidophilus L10 and L. helveticus $\mathrm{H} 100$. An increase in ripening temperature from 4 to 8 and $12{ }^{\circ} \mathrm{C}$ accelerated proteolysis and had a positive effect on the development of ACE inhibition. Cheeses H100 with $L$. helveticus had already reached an optimum degree of ACE inhibition after 12 weeks, whereas the other cheeses showed maximal ACE inhibition at the end of the ripening period. In a previous study [66], the authors investigated the development of ACE inhibition in seven cheese varieties from Switzerland during the period of commercial ripeness. Three loaves of each variety manufactured in different cheese factories were investigated at constant intervals, as follows: Tête de Moine and Vacherin fribourgeois (60-210 d), Appenzell $1 / 4$ fat and Tilsit (90-300 d), Emmental and Gruyère (120 $540 \mathrm{~d})$ and Hobelkäse from the Bernese Oberland (= Bernese Hobelkäse) (360 $720 \mathrm{~d}$ ). Among the three loaves of Bernese Hobelkäse, ACE inhibition showed a large variation, but it remained rather stable in the individual loaves over the whole investigation period (Fig. 1). In Emmental, ACE inhibition increased continuously after an initial drop and reached a plateau after about $400 \mathrm{~d}$. In contrast to this, Gruyère showed its highest ACE inhibition during the initial period of commercial ripeness and a continuous decrease after 9 months of ripening. In the semi-hard cheeses, ACE inhibition increased during ripening, except in an Appenzell $1 / 4$ fat loaf. However, considerable differences were found among the different varieties, as well as among the individual loaves of the same variety. For example, Tilsit showed optimum ACE inhibition after about 7-9 months of ripening, while the rate of increase in ACE inhibition varied considerably in individual loaves of
Tête de Moine and Vacherin fribourgeois and Appenzell $1 / 4$ fat. In summary, the obtained results indicate that development of ACE inhibition is influenced mainly by the individual manufacturing conditions and to a lesser extent by the variety itself.

\section{ACE-INHIBITING PEPTIDES IN CHEESE}

\subsection{ACE-inhibiting cheese peptides showing in vitro activity}

\subsubsection{Isolation and identification of ACE-inhibitory cheese peptides}

Proteolysis is the principal event that occurs during cheese ripening. The continuous breakdown of $\alpha_{\mathrm{s} 1}$-casein (199 amino acids), $\beta$-casein (209 amino acids) and para $\kappa$-casein (105 amino acids $=\mathrm{fl}-105$ of $\kappa$-casein) during cheese ripening into polypeptides and their further degradation into oligopeptides and free amino acids leads to the formation of a vast number of peptides in cheese. The observable changes in ACE inhibition during cheese ripening are related to the release and degradation of peptides with an ACE-inhibitory capacity. High-performance liquid chromatography (HPLC), combined with different mass spectrometry (MS) techniques, has been successfully applied in several studies for the identification and quantification of ACE-inhibiting peptides in cheese [1, 16, $35,84,132]$. However, due to the large number of different peptides present in cheese, the isolation, identification and quantification of ACE-inhibitory peptides remain labour-intensive tasks. Some of the 59 identified ACE-inhibiting peptides originating from $\alpha_{\mathrm{s} 1^{-}}, \beta$ - and $\kappa$-casein [65] have already been found in various cheeses. The peptides listed in Table II were identified in various studies investigating cheese varieties of Italian [118], Spanish [31, 35] and Swiss $[15,16,66]$ origin; in cheeses that 
Table II. Identification of different ACE-inhibiting peptides in cheese.

\begin{tabular}{|c|c|c|}
\hline Cheese & Peptides & $\overline{\text { Reference }}$ \\
\hline Crescenza $^{\mathrm{a}}$ & LVYPFPGPIHNSLPQ ( $\beta-C N(f 58-72))$ & [118] \\
\hline Festivo $^{\mathrm{b}}$ & $\begin{array}{l}\text { RPKHPI, RPKHPIK, RPKHPIKHQ ( } \alpha_{\mathrm{s} 1}-\mathrm{CN} \text { (f1-6), (f1-7), } \\
(\mathrm{f} 1-9))\end{array}$ & {$[102]$} \\
\hline Gouda $^{\mathrm{a}}$ & $\begin{array}{l}\text { RPKHPIKHQ, RPKHPIKHQGLPQ }\left(\alpha_{\mathrm{s} 1}-\mathrm{CN}(\mathrm{f} 1-9),(\mathrm{f} 1-13)\right) \text {, } \\
\text { YPFPGPIPN, MPFPKYPVQPf ( } \beta-\mathrm{CN}(\mathrm{f} 60-68),(\mathrm{f} 109-119))\end{array}$ & [105] \\
\hline Manchego $^{a}$ & $\begin{array}{l}\text { VVAPFPE, FPE, VPSERYL, KKYNVPQ }\left(\alpha_{\mathrm{s} 1}-\mathrm{CN}(\mathrm{f} 24-30) \text {, }\right. \\
(\mathrm{f} 28-30),(\mathrm{f} 86-92),(\mathrm{f} 102-108)) \text {, TQPKTNAIPY, IPY }\left(\alpha_{\mathrm{s} 2}-\mathrm{CN}\right. \\
(\mathrm{f} 195-204),(\mathrm{f} 202-204)), \text { VPKVKE, VPKVKET, VRGPFP }(\beta-\mathrm{CN} \\
(\mathrm{f} 95-100),(\mathrm{f} 95-101),(\mathrm{f} 199-204))\end{array}$ & [32] \\
\hline Manchego $^{\mathrm{a}}$ & $\begin{array}{l}\text { VPSERYL, KKYNVPQL }\left(\alpha_{\mathrm{s} 1}-\mathrm{CN}(\mathrm{f} 86-92),(\mathrm{f} 102-109)\right), \mathrm{VRYL} \\
\left(\alpha_{\mathrm{s} 2}-\mathrm{CN}(\mathrm{f} 205-208)\right) \text {, DKIHPF, LPQNILP }(\beta-\mathrm{CN}(\mathrm{f} 47-52), \\
(\mathrm{f} 70-76))+ \text { other peptides with } \mathrm{IC}_{50} \text { values higher than } 500 \mu \mathrm{M}\end{array}$ & [33] \\
\hline Manchego $^{\mathrm{a}}$ & $\begin{array}{l}\text { QP, PP, FP, PFP (various fragments), HPIK, HQGL }\left(\alpha_{s_{1}-C N}(\mathrm{f} 4-7) \text {, }\right. \\
\text { (f8-11)), DKIHP, DKIHPF, TGPIPN ( } \beta-\mathrm{CN}(\mathrm{f} 47-51),(\mathrm{f} 47-52) \text {, } \\
(\mathrm{f} 63-68))\end{array}$ & [35] \\
\hline Roncal $^{\mathrm{a}}$ & $\begin{array}{l}\text { QP, PP (various fragments), RPKHP, PKHP, HPIK, HQGL }\left(\alpha_{\mathrm{s} 1}-\mathrm{CN}\right. \\
(\mathrm{f} 1-5),(\mathrm{f} 2-5),(\mathrm{f} 4-7),(\mathrm{f} 8-11)), \text { DKIHP, DKIHPF, GPVR }(\beta-\mathrm{CN} \\
(\mathrm{f} 47-51),(\mathrm{f} 47-52),(\mathrm{f} 197-200))\end{array}$ & [35] \\
\hline Idiazábal $^{\mathrm{a}}$ & $\begin{array}{l}\text { QP, FP (various fragments), NINE, PSE, ERYL, PQL, EIVPK, } \\
\text { AWY }\left(\alpha_{\mathrm{s} 1}-\mathrm{CN}(\mathrm{f} 36-39),(\mathrm{f} 87-89),(\mathrm{f} 89-92),(\mathrm{f} 107-109),\right. \\
(\mathrm{f} 110-114),(\mathrm{f} 163-165)), \text { DKIHP, DKIHPF ( } \beta-\mathrm{CN}(\mathrm{f} 47-51) \\
(\mathrm{f} 47-52))\end{array}$ & [35] \\
\hline Mahón ${ }^{\mathrm{a}}$ & $\begin{array}{l}\text { PK, PQ, RI/RL (various fragments), PQEVL, EVLN, NENLL, } \\
\text { ENLL, NLLRF ( } \alpha_{\mathrm{s} 1}-\mathrm{CN} \text { (f12-16), (f14-17), (f17-21), (f18-21), } \\
\text { (f19-23)) }\end{array}$ & [35] \\
\hline Goat cheese $^{\mathrm{a}}$ & $\begin{array}{l}\left.\text { QP, PP (various fragments), RPK ( } \alpha_{\mathrm{s1}}-\mathrm{CN}(\mathrm{f} 1-3)\right), \text { EEL/EEI ( } \beta-\mathrm{CN} \\
\left.(\mathrm{f} 4-7) / \alpha_{\mathrm{s} 2}-\mathrm{CN}(\mathrm{f} 68-70)\right), \text { DKIHP, DKIHPF, PLTQTP, VVVPP, } \\
\text { GVPK, TDVEK, VRGP ( } \beta-\mathrm{CN}(\mathrm{f} 47-51),(\mathrm{f} 47-52),(\mathrm{f} 76-81), \\
(\mathrm{f} 82-86),(\mathrm{f} 94-97),(\mathrm{f} 128-132),(\mathrm{f} 201-204))\end{array}$ & [35] \\
\hline Cabrales $^{\mathrm{a}}$ & $\begin{array}{l}\text { PP, MPI/MPL, EVVR (various fragments), REL, DKIHP, DKIHPF, } \\
\text { FPGPIH, PGPIH, GPIH, PVEP, PVEPF ( } \beta \text {-CN (f1-3), (f47-51), } \\
(\mathrm{f} 47-52),(\mathrm{f} 62-67),(\mathrm{f} 63-67),(\mathrm{f} 64-67),(\mathrm{f} 115-118),(\mathrm{f} 115-119))\end{array}$ & [35] \\
\hline $\begin{array}{l}\text { Cheese-like system } \\
\text { of ovine milk }\end{array}$ & $\begin{array}{l}\text { VPKVK, YQEP, YQEPVLGP ( } \beta \text {-CN (f95-99), (f191-194), } \\
(\text { (f191-198)) + three peaks with sequence not determined }\end{array}$ & [115] \\
\hline $\begin{array}{l}\text { Cheese-like system } \\
\text { of caprine milk }{ }^{\mathrm{a}, \mathrm{c}}\end{array}$ & $\begin{array}{l}\text { RPK, RPKHPIKH }\left(\alpha_{\mathrm{s} 1}-\mathrm{CN}(\mathrm{f} 1-3),(\mathrm{f} 1-8)\right), \text { YQKFPQY }\left(\alpha_{\mathrm{s} 2}-\mathrm{CN}\right. \\
(\mathrm{f} 90-96)), \text { VPKVK, YQEP, YQEPVLGP }(\beta-\mathrm{CN}(\mathrm{f} 95-99), \\
(\mathrm{f} 191-194),(\mathrm{f} 191-198)),+ \text { six peaks with sequence not } \\
\text { determined }\end{array}$ & [115] \\
\hline $\begin{array}{l}\text { Many different Swiss } \\
\text { cheeses }^{\mathrm{a}}\end{array}$ & IPP, VPP ( $\beta-C N$ (f74-76), (f84-86)) & {$[15,16]$} \\
\hline Cheddar $^{\mathrm{a}}$ & $\begin{array}{l}\text { RPKHPI, RPKHPIK, RPKHPIKHQ (= fraction 9), FVAPFPEVF, } \\
\text { KKYKVPQLE (= fraction 27) }\left(\alpha_{\mathrm{s} 1} \text {-CN (f1-6), (f1-7), (f1-9), }\right. \\
\text { (f24-32), (f102-110)), DKIHPF (= fraction 15), } \\
\text { YQEPVLGPVRGPFPIIV (= fraction 28) }(\beta-\mathrm{CN}(\mathrm{f} 47-52), \\
\text { (f193-209)) }\end{array}$ & [86] \\
\hline
\end{tabular}


Table II. Continued.

\begin{tabular}{|c|c|c|}
\hline Cheese & Peptides & Reference \\
\hline Cheddar $^{\mathrm{a}}$ & 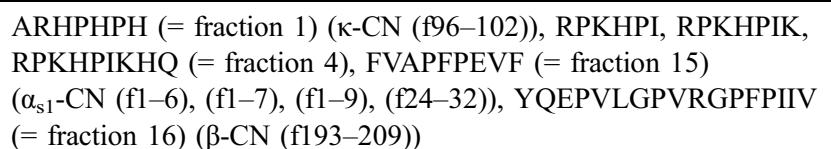 & [88] \\
\hline $\begin{array}{l}\text { Enzyme-modified } \\
\text { cheese }\end{array}$ & LQP, MAP ( $\beta$-CN (f88-90), (f102-104)) & [125] \\
\hline
\end{tabular}

${ }^{a}$ Water-soluble cheese fraction.

${ }^{b}$ Ethanol-soluble cheese fraction.

${ }^{\mathrm{c}}$ Prepared with proteases from Cynara cardunculus.

One-letter abbreviations of amino acids: $\mathrm{A}=$ alanine, $\mathrm{C}=$ cysteine, $\mathrm{D}=$ asparagic acid, $\mathrm{E}=$ glutamic acid, $\mathrm{F}=$ phenylalanine, $\mathrm{G}=$ glycine, $\mathrm{H}=$ histidine, $\mathrm{I}=$ isoleucine, $\mathrm{K}=$ lysine, $\mathrm{L}=$ leucine, $\mathrm{M}=$ methionine, $\mathrm{N}=$ asparagine, $\mathrm{P}=$ proline, $\mathrm{Q}=$ glutamine, $\mathrm{R}=$ arginine, $\mathrm{S}=$ serine, $\mathrm{T}=$ threonine, $\mathrm{V}=$ valine, $\mathrm{W}=$ tryptophan and $\mathrm{Y}=$ tyrosine.

are obtainable on the Japanese market [105]; in probiotic cheeses [86, 88, 102]; and in cheese-like systems of ovine and caprine milk [115]. Additionally, LQP and MAP, two ACE-inhibitory peptides derived from $\beta$-casein (f88-90 and f102-104, respectively), were found in enzyme-modified cheeses [125]. The obtained results indicate that a large number and diversity of peptides contribute to the ACE-inhibitory effect obtained with cheese extracts during in vitro experiments. Only few of the identified ACE-inhibitory peptides seem to represent orally active ACE inhibitors, as most of these peptides are likely to be further degraded during gastrointestinal transit.

\subsubsection{Quantification of $A C E-$ inhibiting peptides during cheese ripening}

Several studies have confirmed that the ACE-inhibitory activity of cheese extracts is considerably influenced by cheese ripening. In order to meet the requirements for the development of an antihypertensive cheese, a reproducible release of orally active ACE-inhibitory peptides and a good control of their concentrations during cheese ripening would be essential. In a recent study, Gómez-Ruiz et al. [33] investigated the formation of five ACE-inhibitory peptides in four different batches of Manchego cheese manufactured from raw or pasteurized ovine milk with different cultures during cheese ripening. The five investigated peptides, VRYL (for the one-letter abbreviations of amino acids, see Tab. II), DKIHPF, LPQNILP, VPSERYL and KKYNVPQL, all showed remarkable ACE-inhibitory activity $\left(\mathrm{IC}_{50}\right.$ values 24.1, 256.8, 46.0, 232.8 and $77.1 \mu \mathrm{mol} \cdot \mathrm{L}^{-1}$, respectively). The amounts of VRYL, DKIHPF and LPQNILP were generally higher than those of VPSERYL and KKYNVPQL and were highest in raw-milk cheese. However, the amounts of all five peptides varied considerably in the individual cheeses over the ripening period of 12 months.

Ong et al. [86] studied the release of ACE-inhibitory peptides in three variants of Cheddar cheeses made with starter lactococci (control) and probiotic adjuncts (L. casei 279 or L. casei LAFTI $^{\circledR}$ L26). The following seven ACE-inhibitory peptides were identified in four different fractions: RPKHPIKHQ, RPKHPIK, RPKHPI, DKIHPF, FVAPFPEVF, KKYKVPQLE 
and YQEPVLGPVRGPFPIIV (Tab. II). The total areas of the four fractions were quantified after ripening periods of 0,12 , 24 and 36 weeks. The obtained results showed a rather uniform development for all three variants of Cheddar cheese. With few exceptions, the four investigated fractions reached a maximum ACE-inhibitory effect after 12-24 weeks of ripening. In a similar study [88], the same research group investigated the release of ACEinhibitory peptides in seven batches of Cheddar cheese manufactured with different probiotic adjuncts (B. longum, B. animalis ssp. lactis LAFTI B94, L. casei 279, L. casei LAFTI L26, L. acidophilus 4962 and L. acidophilus LAFTI L10) that were stored at ripening temperatures of $4{ }^{\circ} \mathrm{C}$ and $8^{\circ} \mathrm{C}$ for 24 weeks. In this study, a total of six peptides were identified in four fractions of a water-soluble extract: ARHPHPH, RPKHPIKHQ, RPKHPIK, RPKHPI, FVAPFPEVF and YQEPVLGPVRGPFPIIV (Tab. II). With few exceptions, all variants showed similar trends for the release of the ACE-inhibitory peptides. Most of the ACEinhibitory peptides accumulated in the early stages of ripening. However, in contrast to the previous study, the behaviour of the fraction containing the peptides RPKHPIKHQ, RPKHPIK and RPKHPI differed significantly. The obtained results indicate that it may be difficult to influence and control the release of specific ACE-inhibitory peptides during ripening.

\subsection{ACE-inhibitory peptides VPP and IPP}

\subsubsection{Commercial use of the ACE- inhibitory peptides VPP and IPP}

Two lactotripeptides, valyl-prolyl-proline (Val-Pro-Pro, VPP) and isoleucyl-prolylproline (Ile-Pro-Pro, IPP), have attracted great attention during the past few years due to their commercial use in hypotensive milk-drink products, such as Ameal $\mathrm{S}^{\mathrm{TM}}$ (Calpis Company, Japan) and Evolus ${ }^{\circledR}$ (Valio, Finland). Several patents have been filed in order to protect their commercial use $[78,126]$. The two peptides were initially isolated from milk fermented with L. helveticus and Saccharomyces cerevisiae. VPP is located in the sequence f84-86 of $\beta$-casein and IPP in $\mathrm{f74}-76$ of $\beta$-casein as well as f108-110 of $\kappa$-casein [79]. According to in vitro studies, they have $\mathrm{IC}_{50}$ values of $9.13 \pm 0.21$ and $5.15 \pm 0.17 \mu \mathrm{mol} \cdot \mathrm{L}^{-1}$, respectively [89]. Comprehensive toxicological studies have been conducted with no adverse effects found $[10-12,22,44$, $51,55,56,73,77,92,106]$. The following toxicological methods were used: singleand repeated-dose toxicity, 13-week toxicity, fertility and reproductive performance, micronucleus test, cytotoxicity and clastogenicity, and mutagenicity.

Numerous in vivo studies confirmed the antihypertensive effect of the two lactopeptides in spontaneously hypertensive rats (SHR) [27, 80, 116, 117, 138, 139], as well as in mildly hypertensive patients [3, 37, 42 , $72,74,109,110,128]$. Nine studies including 12 randomized controlled trials published between 1996 and 2005 with a total of 623 participants were included in a meta-analysis. Significant decreases of $4.8 \mathrm{mmHg}(95 \%$ confidence interval 3.7-6.0) in SBP and $2.2 \mathrm{mmHg}$ (95\% confidence interval 1.3-3.1) in diastolic blood pressure (DBP) were found after the pooling of these trials [136]. Another meta-analysis, including 15 placebo-controlled clinical studies, showed a significant reduction of $5.13 \mathrm{mmHg}$ in SBP and $2.42 \mathrm{mmHg}$ in DBP caused by bioactive peptides that were derived from food proteins [94]. However, the antihypertensive effect of fermented milk is still debatable. In three recent human studies - two of them including multicentre, double-blind, parallel, placebo-controlled trials - no blood pressure-lowering effect 
Table III. Sum of the concentration of VPP + IPP in extra-hard, hard and semi-hard cheeses of Swiss origin $\left(\mathrm{mg} \cdot \mathrm{kg}^{-1}\right)$ [15].

\begin{tabular}{lrrrrr}
\hline Cheese & \multicolumn{1}{c}{$n$} & \multicolumn{1}{c}{$x$} & \multicolumn{1}{c}{$s_{x}$} & Min & Max \\
\hline Extra-hard and hard cheeses & & & & & \\
Bernese Alpkäse & 11 & 121.9 & 148.0 & 10.7 & 424.5 \\
Bernese Hobelkäse & 23 & 129.8 & 132.0 & 6.8 & 353.0 \\
L'Etivaz à rebibes & 3 & 19.1 & 9.6 & 9.4 & 28.6 \\
Sbrinz & 7 & 37.7 & 27.2 & 1.6 & 90.5 \\
Emmental & 20 & 89.6 & 50.9 & 31.3 & 189.5 \\
Gruyère & 9 & 61.4 & 33.6 & 21.6 & 129.0 \\
Semi-hard cheeses & & & & & \\
Appenzell, full fat & 6 & 61.5 & 27.4 & 30.5 & 96.0 \\
Appenzell, 1/4 fat & 4 & 182.2 & 103.6 & 66.4 & 317.4 \\
Tilsit & 6 & 96.8 & 40.1 & 57.2 & 150.3 \\
Tête de Moine & 6 & 105.3 & 49.2 & 52.4 & 189.8 \\
Vacherin fribourgeois & 6 & 31.8 & 38.8 & 6.5 & 108.8 \\
\hline
\end{tabular}

was found after administration of a dairy drink with lactotripeptides [23, 130, 131].

\subsubsection{Occurrence of VPP and IPP in different cheese varieties}

Selected strains of L. helveticus have been shown to be responsible for the release of the antihypertensive peptides VPP and IPP [78, 126]. Strains of L. helveticus are often included in cultures for the manufacture of cheese due to their high proteolytic activity [48]. The sequence X-Pro-Pro is likely to be particularly stable against peptidases [19, 59]. Bernard et al. [12] first mentioned the occurrence of VPP and IPP in cheese and indicated a remarkably high concentration of $566.88 \mathrm{mg} \cdot \mathrm{kg}^{-1}$ VPP + IPP for Blue cheese and varying concentrations in the range of $9.66-189.15 \mathrm{mg} \cdot \mathrm{kg}^{-1}$ for Cheddar cheese. Recently, we obtained a similar concentration of $570.4 \mathrm{mg} \cdot \mathrm{kg}^{-1}$ VPP + IPP in an experimental semi-hard cheese after 6 months of ripening (unpublished study). In two other studies performed at our Research Station, we quantified the two tripeptides in various cheese varieties of Swiss and foreign origin. In a first study
[16], we investigated a total of 44 commercial cheese samples, including extra-hard, hard, semi-hard and soft cheeses. Twelve samples of extra-hard and hard cheeses contained, on average, $100 \pm 92 \mathrm{mg} \cdot \mathrm{kg}^{-1}$ VPP + IPP, and another 21 samples of semi-hard cheese varieties contained $52 \pm 50 \mathrm{mg} \cdot \mathrm{kg}^{-1}$ VPP + IPP, while only minor concentrations of the tripeptides were found in 11 samples of soft cheese (average $\left.3 \pm 6 \mathrm{mg} \cdot \mathrm{kg}^{-1} \mathrm{VPP}+\mathrm{IPP}\right)$, probably due to the lower degree of proteolysis. In a second study [15], we focused on six varieties of extra-hard and hard cheeses and five varieties of semi-hard cheese of Swiss origin that showed elevated concentrations of VPP + IPP in the first study. The average concentrations of VPP + IPP in extra-hard and hard cheeses came close to the values in the first study (95.8 $\pm 102.2 \mathrm{mg} \cdot \mathrm{kg}^{-1}, 73$ samples). However, a distinctly higher average concentration of $89.3 \pm 67.9 \mathrm{mg} \cdot \mathrm{kg}^{-1}$ VPP + IPP was obtained for the 28 samples of the selected semi-hard cheese varieties. The values obtained for the individual varieties are summarized in Table III. The results of the second study confirmed that various traditional cheese varieties contain, 


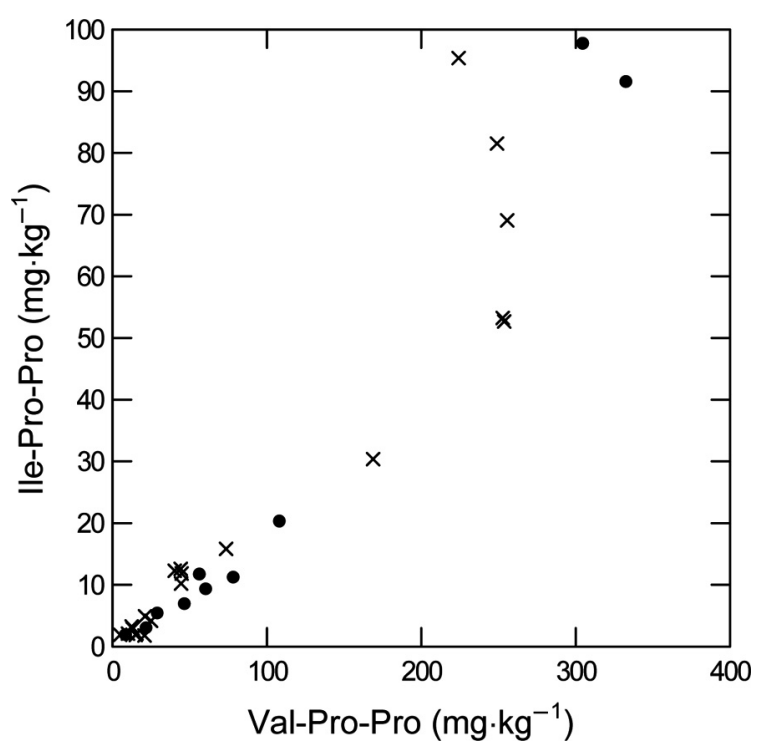

Figure 2. Concentrations of VPP and IPP obtained in individual samples of Bernese Hobelkäse $(\times)$ and its less-ripened precursor, Alpkäse $(\bullet)$ [15].

on average, similar concentrations of the two antihypertensive peptides when compared to the recently developed fermented-milk products with blood pressure-lowering properties. However, the individual data for the 11 surveyed cheese varieties indicate that great variation exists between coeval samples of the same variety. The greatest variations were observed in Bernese Hobelkäse (minimum ripening time 18 months) and its precursor, Bernese Alpkäse (minimum ripening time 6 months). In the case of the Alpkäse, the values for VPP and IPP were spread throughout the full range, while in the Bernese Hobelkäse, two different groups were found (Fig. 2).

\subsubsection{Quantification of VPP and IPP during cheese ripening}

Several studies have shown that the ACE-inhibitory activity in water-soluble cheese extracts is influenced by the duration of cheese ripening [66, 86-88, 102]. In parallel to ACE inhibition (see Sect. 2.2), we monitored the concentrations of VPP and IPP in three loaves each of seven cheese varieties during ripening (see Sect. 2.2) [66]. The individual values for the 21 cheeses showed obvious parallels between ACE inhibition and the concentration of VPP and IPP (Figs. 1, 3 and 4). In contrast to the concentrations of VPP and IPP, higher levels of ACE inhibition may occur in the early stages of ripening due to the release of ACE-inhibiting peptides other than VPP and IPP. The best agreement between ACE inhibition and the concentration of VPP + IPP is to be expected at advanced stages of ripening, due to the lower susceptibility of VPP and IPP to further degradation. Although both peptides occur in the sequence of $\beta$-casein, the concentration of VPP was always higher than that of IPP. In the case of Bernese Hobelkäse and Gruyère, the total concentrations of VPP and IPP decreased during the period of commercial ripeness. In the three loaves of Emmental and Tilsit, the total concentrations increased initially and reached 


\section{Bernese Hobelkäse}

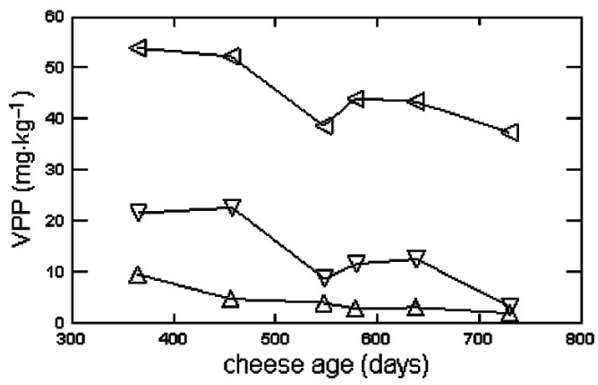

\section{Emmental}

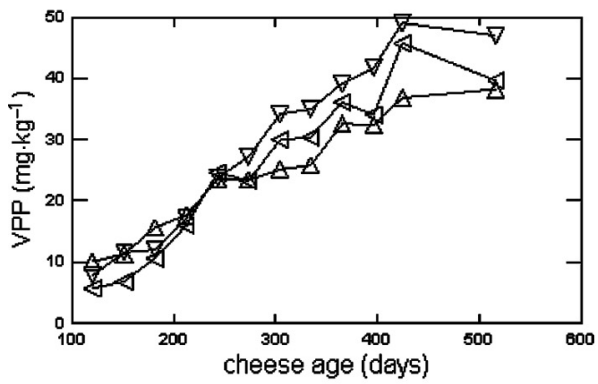

\section{Gruyère}

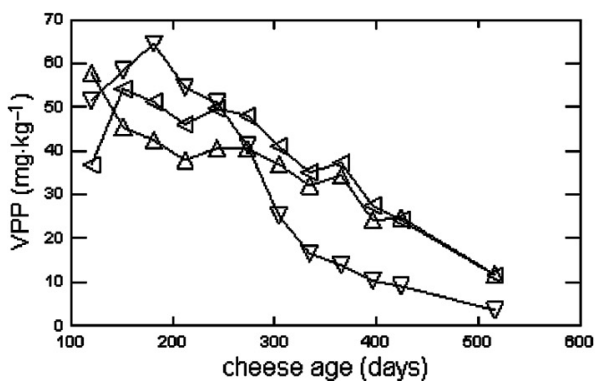

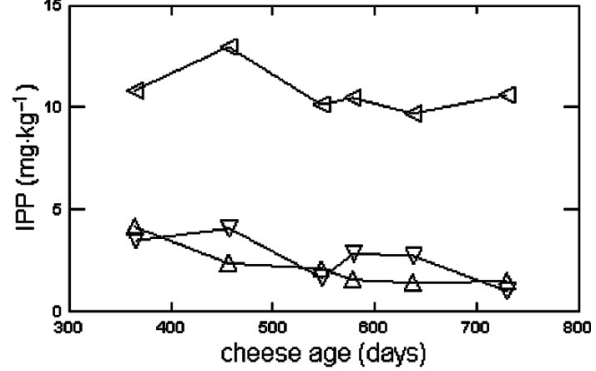
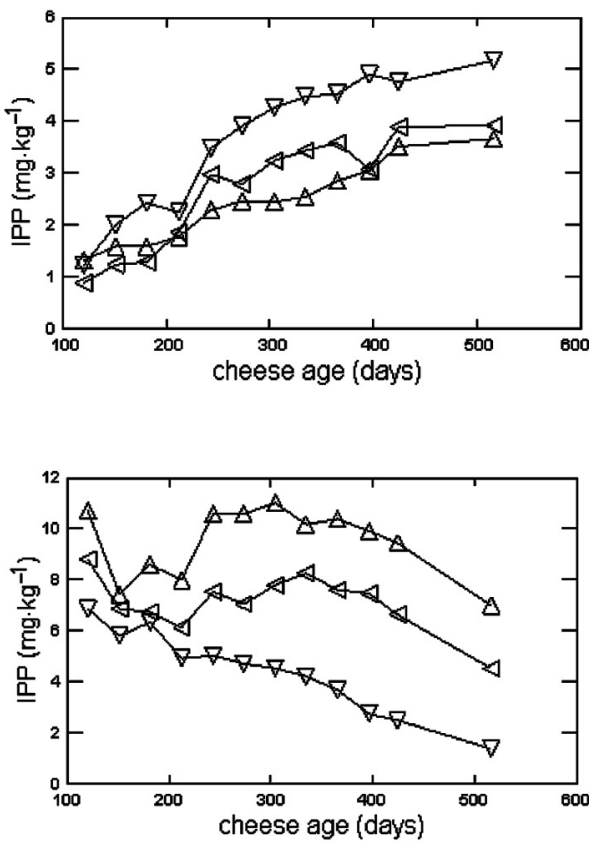

Figure 3. Behaviour of VPP and IPP during ripening of extra-hard and hard cheeses of Swiss origin (unpublished data from [66]).

a maximum toward the end of the study period. However, large differences were obtained among the individual loaves of Appenzell $1 / 4$ fat, Tête de Moine and Vacherin fribourgeois (Figs. 3 and 4). Chemical characterization of the investigated cheeses revealed that qualitative differences in the proteolysis pattern, not quantitative differences in the degree of proteolysis, are responsible for the observed variations in the concentrations of VPP and IPP.

\subsection{Factors that influence the release of ACE-inhibitory peptides}

The concentrations of ACE-inhibiting peptides VPP and IPP in cheese seem to 
Appenzell $1 / 4$ fat
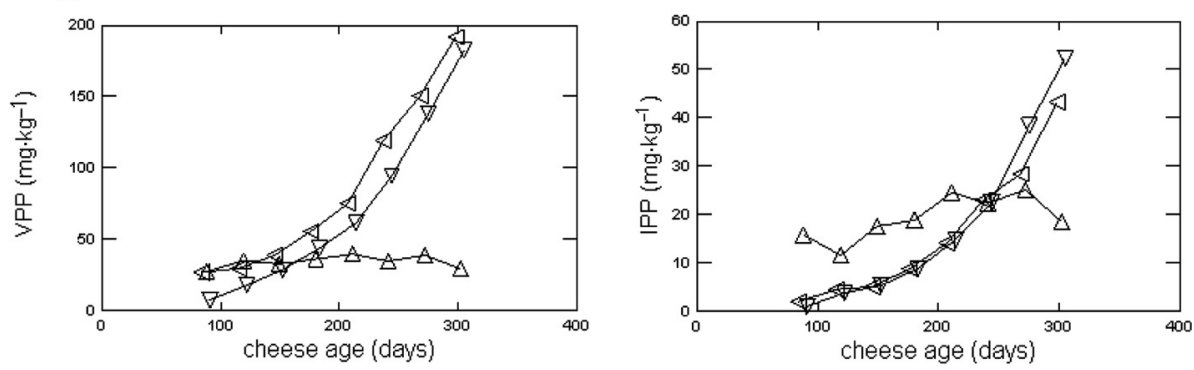

Tilsit from raw milk
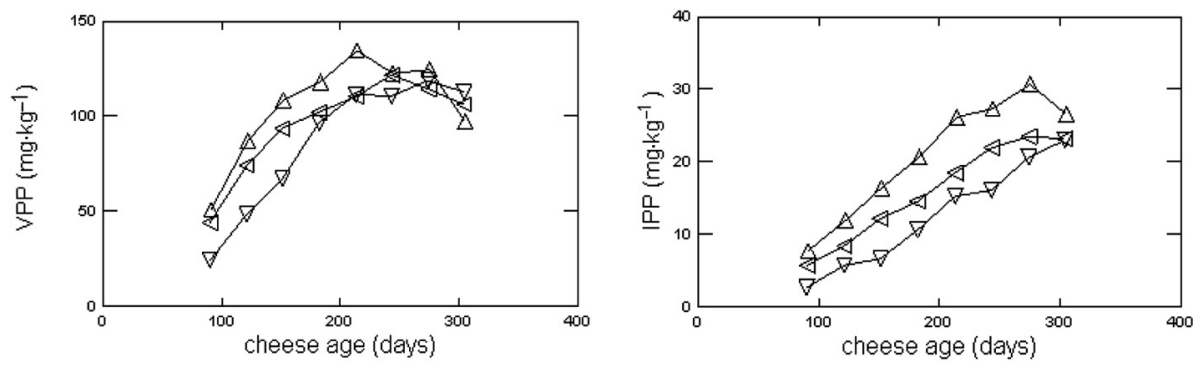

Tête de Moine
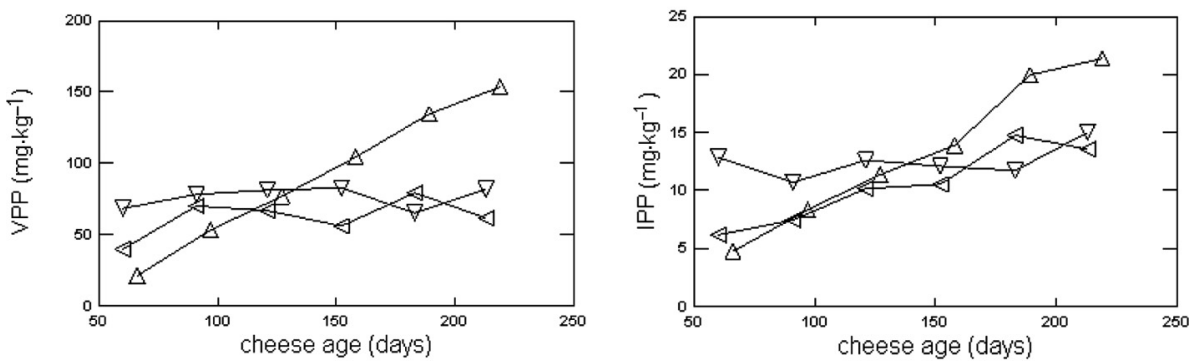

Vacherin fribourgeois
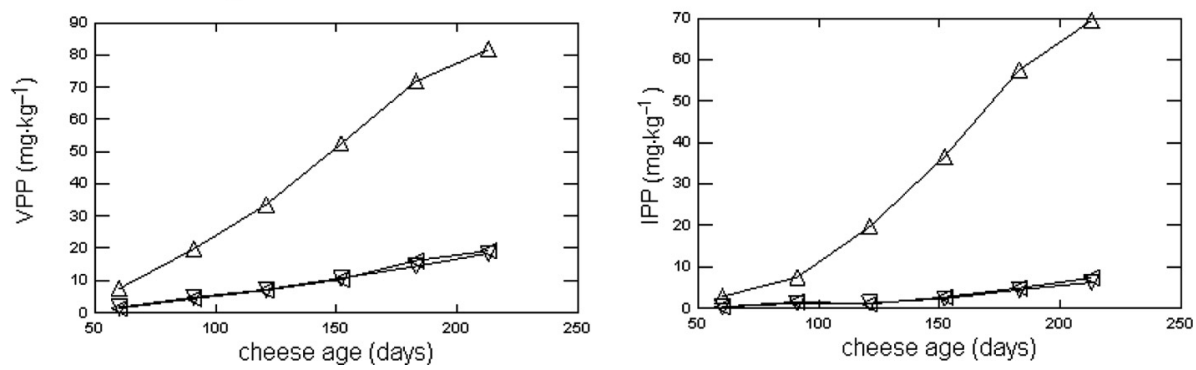

Figure 4. Behaviour of VPP and IPP during ripening of semi-hard cheeses of Swiss origin (unpublished data from [66]). 
Table IV. Release of VPP and IPP in differently pretreated skimmed milk after incubation with L. helveticus strain FAM 12111 at $37{ }^{\circ} \mathrm{C}$ for $24 \mathrm{~h}$ (mean $\pm \mathrm{SD} ; n=2$ ).

\begin{tabular}{llrr}
\hline Milk pretreatment & \multicolumn{1}{c}{ Conditions } & VPP $\left(\mathrm{mg} \cdot \mathrm{kg}^{-1}\right)$ & IPP $\left(\mathrm{mg} \cdot \mathrm{kg}^{-1}\right)$ \\
\hline Microfiltration & $55^{\circ} \mathrm{C}$, several seconds & $2.2 \pm 0.1$ & $2.0 \pm 0.0$ \\
Pasteurization & $78^{\circ} \mathrm{C}$, several seconds & $4.4 \pm 0.5$ & $3.8 \pm 0.4$ \\
Pasteurization & $90^{\circ} \mathrm{C}, 30$ min & $14.2 \pm 1.3$ & $7.6 \pm 0.9$ \\
UHT & $135^{\circ} \mathrm{C}, 5 \mathrm{~s}$ & $13.3 \pm 0.1$ & $7.9 \pm 0.6$ \\
\hline
\end{tabular}

be influenced by various factors, such as cultures, milk pretreatment, scalding and ripening conditions. In order to develop a reproducible cheesemaking process that yields cheeses with maximal concentrations of VPP and IPP, it is essential to investigate the quantitative impact of the above-mentioned factors on the release of VPP and IPP.

\subsubsection{Heat treatments of milk and cheese curd}

Heat treatments applied in the process of cheesemaking induce various effects that influence proteolysis in cheese, due to the elimination of raw-milk flora, denaturation of whey proteins, plasminogen activation or inactivation of milk-clotting and microbial enzymes. The average concentrations of VPP + IPP obtained in cheese varieties made from raw milk decreased with increasing scalding temperatures. In L'Etivaz à rebibes $\left(56-57^{\circ} \mathrm{C}\right)$, Sbrinz $\left(57^{\circ} \mathrm{C}\right)$, Gruyère $\left(57^{\circ} \mathrm{C}\right)$, Emmental $\left(52-54^{\circ} \mathrm{C}\right)$, Bernese Hobelkäse $\left(50^{\circ} \mathrm{C}\right)$ and Tête de Moine $\left(46-53{ }^{\circ} \mathrm{C}\right)$, the average concentrations of VPP + IPP were 19.1，37.7，61.4, 89.6, 129.8 and $105.3 \mathrm{mg} \cdot \mathrm{kg}^{-1}$, respectively [15]. Contrarily, in skimmed milk subjected to different pretreatments and then incubated with $L$. helveticus strain FAM 12111 for $24 \mathrm{~h}$ at $37^{\circ} \mathrm{C}$, severe heat treatments promoted the release of VPP and IPP, probably due to changes in the conformation of $\beta$-casein (Tab. IV, unpublished results). However, under normal cheesemaking conditions, conformational changes in $\beta$ casein are not to be expected.

\subsubsection{Starter cultures}

The strains L. helveticus CP790 [57, 137] and L. helveticus LBK-16 [110] have been successfully applied for the formation of VPP and IPP in two commercial fermented-milk products with antihypertensive capacity (Ameal $\mathrm{S}^{\mathrm{TM}}$ and Evolus ${ }^{\circledR}$ ). Similarly, other $L$. helveticus strains such as NCC 2765 [100], PR4 [69] or 130B4 from camel milk [113] and in a further study [82] two highly proteolytic strains of $L$. helveticus (MI 1198, MI 1263), as well as strains of Lc. lactis ssp. lactis (CHCC 3906, CHCC 3923) and Lc. lactis ssp. cremoris (F3, W5) have been reported to release remarkable amounts of ACE-inhibitory peptides. Additionally, the potential of other lactic acid bacterial strains, such as $L$. delbrueckii ssp. bulgaricus SS1, Lc. lactis ssp. cremoris FT4 [30], L. rhamnosus in combination with pepsin and Corolase PP [38], L. delbrueckii ssp. bulgaricus and Str. thermophilus + Lc. lactis ssp. lactis biovar diacetylactis [6], has been investigated in several other studies. Strains of L. helveticus are homofermentative thermophilic and proteolytic lactic acid bacteria that are frequently used in the manufacture of cheese, as they contribute to flavour and texture development and decrease bitterness by hydrolysing bitter peptides. At least 11 peptidases from $L$. helveticus have been 


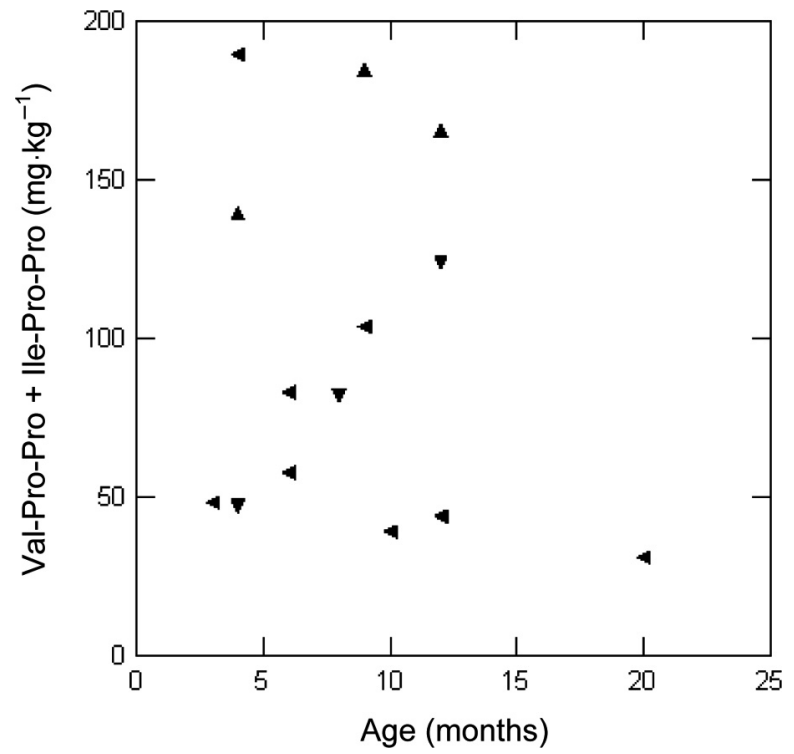

Figure 5. Concentrations of VPP + IPP obtained in individual samples of Emmental of different ages manufactured from conventional milk $(\boldsymbol{\nabla})$, from organic milk $(\varangle)$, or with the addition of a traditional whey culture containing L. helveticus $(\mathbf{\Delta})$.

characterized, including general aminopeptidases PepC and PepN; proline-specific peptidases PepX, PepI, PepQ and PepR; dipeptidases PepD and PepV; endopeptidases PepE and PepO [19]; and, more recently, a tripeptidase, PepT [107]. The proteolytic activity of selected strains of $L$. helveticus also seems to be a key factor for the release of VPP and IPP during cheese ripening. Yamamoto et al. [137] purified a cell wall-associated proteinase from $L$. helveticus CP790 that released 15 ACE-inhibitory peptides from $\beta$-casein and 10 from $\alpha_{\mathrm{s} 1}$-casein. In contrast to this, milk fermented with $L$. helveticus 791 , a variant defective for proteinase activity, did not show this activity. Similarly, the results of our studies $[15,66]$ suggest that the release of VPP and IPP requires a specific breakdown of $\beta$-casein. Manufacturing conditions, such as milk pretreatment, scalding conditions and minimal ripening time, are usually well standardized for a certain cheese variety, and thus would not explain the large variations observed in the concentrations of VPP and IPP within several cheese varieties of Swiss origin. In addition, we observed distinct higher concentrations of VPP and IPP in various cheeses that were made with the addition of $L$. helveticus. For example, three Emmental cheeses produced with a traditional whey culture containing L. helveticus showed, after ripening periods of 4, 9 and 12 months, a total concentration of the two lactotripeptides of 139.3, 184.6 and $165.6 \mathrm{mg} \cdot \mathrm{kg}^{-1}$, respectively; the average concentration in 20 samples of this variety was $89.6 \mathrm{mg} \cdot \mathrm{kg}^{-1}$ (Fig. 5). However, further studies will have to show whether interactions of $L$. helveticus with other lactic acid bacteria that are present in raw milk or cheese cultures have an influence on the concentrations of VPP and IPP in cheese. 


\subsubsection{Ripening time and temperature}

Cheese ripening has an important influence on ACE-inhibitory peptides because proteolysis is continuously increasing [66] (see also Sect. 3.2.2 and Fig. 1). In ripened semi-hard, hard and extra-hard cheeses, the share of free amino acids is usually in the range of $5-15 \%[7,8,108,119-122]$. Low concentrations of VPP and IPP were obtained in soft cheeses due to weaker indepth proteolysis. Although overall proteolysis leads to the release of a large number of water-soluble peptides, ripening per se does not yield high concentrations of the two lactopeptides, as has been shown for 14 commercial samples of Emmental cheese in Figure 5 [16]. In recent studies, increased ripening temperatures were applied in order to increase the ACE-inhibitory activity of Cheddar [87, 88]. However, in contrast to the choice of the culture, the acceleration of overall proteolysis by increased storage temperature is likely to be a rather unspecific measure for the increase of VPP and IPP in cheese.

\subsubsection{Enzymes}

There is little information about the influence of individual proteases and peptidases on the formation of ACE-inhibiting peptides in cheese. For the manufacture of an enzyme-modified cheese with ACEinhibitory activity, chopped Danish skimmilk cheese was mixed with Lactococcus starter cultures and subjected to a serial treatment with proteolytic enzyme preparations (Protease N Amano from Bacillus subtilis, Umamizyme and Flavourzyme from Aspergillus oryzae). Two ACE-inhibitory peptides were obtained and identified as LQP and MAP, originating from $\beta$-casein $888-90$ and f102-104 [125]. Further studies will have to show whether addition of cell wall-associated proteases of $L$. helveticus enhances the release of orally active ACE-inhibitory lactotripeptides, such as VPP and IPP.

\section{ORALLY ACTIVE ACE-INHIBITORY PEPTIDES}

Bioactive peptides have been defined as "peptides with hormone- or drug-like activity that eventually modulate physiological function through binding interactions to specific receptors on target cells leading to induction of physiological responses" [24]. The bioavailability of such peptides is an important prerequisite in order to obtain effects in vivo. Only few ACE-inhibitory peptides isolated from cheese have been shown to be orally active. Among these peptides, the two lactotripeptides VPP and IPP have been the subject of various in vivo studies using fermented-milk products [13]. Additionally, a potent ACE-inhibiting effect was obtained in both hypertensive and prehypertensive humans in a double-blind, placebo-controlled trial with a bovine casein hydrolysate [17, 127]. The effect was attributed to a longer peptide representing the sequence f23-34 of $\alpha_{\mathrm{s} 1}$-casein [25], but it remains questionable whether such peptides can be absorbed in an intact form.

\subsection{Digestion and absorption of orally active peptides}

Several studies investigated the impact of gastrointestinal digestion on the release and degradation of ACE-inhibitory peptides. According to Hernández-Ledesma et al. [38], gastrointestinal digestion of fermented milks promotes the formation of active peptides. Parrot et al. [90] investigated the ACE-inhibitory activity of watersoluble extracts of Emmental before and after incubation with gastric enzymes. After digestion by pepsin and trypsin or by pepsin and pancreatin, the $\mathrm{IC}_{50}$ values decreased by $33 \pm 13 \%$ and $32 \pm 13 \%$, respectively. In another study [32], the simulated digestion of 11 ACE-inhibiting peptides yielded only four resistant peptides (FP, IPY, LEIVPK and VRGFPF). The same peptides were previously identified in Manchego 
cheese (see Sect. 3.1.2). However, for two peptides, VRYL and KKYNVPQL, that showed the highest ACE-inhibitory activity $\left(\mathrm{IC}_{50}\right.$ values of 24.1 and $77.1 \mu \mathrm{mol} \cdot \mathrm{L}^{-1}$, respectively), a decrease in ACE-inhibitory activity was observed during simulated digestion. Ohsawa et al. [84] treated $\beta$-casein and aqueous solutions of synthetic VPP and IPP with different digestive enzymes in a two-stage in vitro model. In an initial stage, pepsin, pancreatin or trypsin/chymotrypsin was used; a second stage employed Caco-2 cells containing aminopeptidases $\mathrm{N}, \mathrm{P}$ and $\mathrm{W}$, dipeptidyl peptidase IV, endopeptidase-24.11, $\gamma$-glutamyl transpeptidase, microsomal dipeptidase and peptidyl dipeptidase A. Synthetic VPP and IPP were highly resistant to the effects of the above-mentioned gastrointestinal enzymes, and thus would reach the small intestine in intact form. Neither VPP nor IPP was generated from $\beta$-casein, although different larger peptides containing the VPP sequence were formed. Additionally, various other functional peptide sequences were released from $\beta$-casein by in vitro digestion. The results of the above-mentioned studies suggest that the resistance of peptides to gastrointestinal digestion is an important prerequisite in order to obtain physiological effects in vivo after oral administration of bioactive peptides. However, the bioavailability of such digestion-resistant peptides is also strongly influenced by their absorption. Masuda et al. [59] showed that VPP and IPP reach the abdominal aorta of SHR after the oral administration of Calpis sour milk (Ameal $\mathrm{S}^{\mathrm{TM}}$ ) and reported a recovery of $4.0 \%$ and $5.0 \%$ of tripeptides ingested, respectively. Similarly, in rats, ${ }^{14} \mathrm{C}$-labelled IPP was absorbed partially intact. The highest blood concentration of total radioactivity was observed $2 \mathrm{~h}$ after oral administration, and only $11.8 \%$ of the administered radioactivity was excreted at $48 \mathrm{~h}$ post-dose [43]. In humans, this peptide was absorbed intact into the circulation after the consumption of a lactotripeptide-enriched milk beverage [26]. Similarly, the use of HPLC-multiple reaction monitoring mass spectrometry (HPLC-MRM-MS) confirmed the presence of the peptides AW, VF, VY, IWR, HLP, LPP, VPP, LPPR and HLPLP in human plasma [132]. However, a recent study [129] investigating the pharmacokinetics of intravenously or intragastrically administered synthetic IPP, LPP and VPP in pigs showed that the absolute bioavailability of intragastrically infused tripeptides was only about $0.1 \%$, and that half-lives of absorption and elimination were maximally about 5 and $15 \mathrm{~min}$, respectively. This study concluded that under these conditions, the bioactive effect of these tripeptides would be rather acute.

\subsection{Antihypertensive effects of cheese in vivo}

In recently launched commercial sour milks that have been shown to be effective against hypertension, doses of about $5 \mathrm{mg} \cdot \mathrm{d}^{-1}$ VPP + IPP were applied [37, 41, $109,128]$. The discovery of the same orally active ACE-inhibitory lactotripeptides in various varieties of cheese in concentrations up to 566.88 [12] and $570.4 \mathrm{mg} \cdot \mathrm{kg}^{-1}$ (unpublished study) is a promising feature with regard to nutrition and consumption of cheese. However, the blood pressurelowering effect of cheese containing high concentrations of VPP and IPP has not yet been demonstrated. Nevertheless, a hypotensive effect was noted in SHR fed water-soluble peptides of different cheeses by gastric intubation. After $6 \mathrm{~h}$ of oral administration, the SBP was measured using the tail-cuff method. Depending on cheese variety, the following decreases in SBP (mmHg) were observed: Gouda (aged 8 months) -24.7 (significantly different from control, $P \leq 0.01)$, Edam -20.7 $(P \leq 0.05)$, Blue $-20.3(P \leq 0.05)$, Havarti -20.0 ( $P \leq 0.01)$, Gouda (aged 24 months) -17.2, Emmental -13.0 and Camembert 
-7.1. In contrast to this, in vitro ACE inhibition of the same cheese extracts showed a rather different order: Gouda (aged 24 months) $78.2 \%$, followed by Gouda (aged 8 months) $75.5 \%$, Havarti $72.7 \%$, Camembert $69.1 \%$, Edam $56.2 \%$, Blue $49.9 \%$ and Emmental $48.8 \%$. Further, six orally administered peptide fractions (dose $6.1-7.5 \mathrm{mg} \cdot \mathrm{kg}^{-1}$ body weight) obtained from the 8-month Gouda decreased SBP in SHR in the range of -10.8 to $-29.3 \mathrm{mmHg}$. Among four identified peptides (Tab. II) the two chemically synthesized nonapeptides (RPKHPIKHQ and YPFPGPIPN) showed antihypertensive effects on SHR of $-9.3 \pm 4.8$ and $-7.0 \pm$ $3.8 \mathrm{mmHg}$, respectively [105]. In another study [125], the peptide MAP, isolated from enzyme-modified cheese and administered to SHR at a dose of $3 \mathrm{mg} \cdot \mathrm{kg}^{-1}$ body weight, reduced SBP by $-17 \mathrm{mmHg}$ as measured by the tail-cuff method $8 \mathrm{~h}$ after gastric intubation.

\section{CONCLUSION}

During cheese ripening, a large number of peptides of variable chain length are released that have been shown to exert an ACE-inhibitory activity in vitro. The ACE-inhibitory activity is attributable to a multitude of unspecific peptides of variable chain length and amino acid sequence. Most of these peptides are to be considered intermediates that are further hydrolysed during cheese ripening or during gastrointestinal transit. Several studies have demonstrated that smaller ACE-inhibitory cheese peptides are absorbed into blood circulation and exert an antihypertensive effect in vivo. Among these peptides, the tripeptides VPP and IPP have been the subject of various in vivo studies. In several human studies, doses of about $5 \mathrm{mg} \cdot \mathrm{d}^{-1}$ VPP + IPP have been shown to reduce blood pressure in both hypertensive and prehypertensive subjects. The discovery of the same orally active ACE-inhibitory lactotripeptides in various cheese varieties in a total concentration of up to $570.4 \mathrm{mg} \cdot \mathrm{kg}^{-1}$ is a promising feature with regard to nutrition and consumption of cheese, but it would require the manufacture of cheeses with constant and reproducible levels of orally active ACE-inhibitory peptides. Recent studies show that overall proteolysis in semi-hard and hard cheese does not necessarily yield high concentrations of the two lactopeptides during ripening. The release of VPP and IPP in cheese seems to be a rather specific process that is, as in fermented milks, strongly enhanced by the proteolytic action of selected strains of $L$. helveticus. However, other factors, such as pretreatment of cheese milk, scalding and ripening time, have been shown to influence the concentrations of these two tripeptides as well. Although doses of up to $30 \mathrm{mg}$ of VPP and IPP can be achieved in a daily portion of cheese, further studies will have to show whether consumption of cheeses with high concentrations of orally active ACE-inhibitory peptides can lower blood pressure. Recently, rather conflicting results were obtained in three human studies for VPP and IPP. Additionally, the absorption of ACE-inhibitory peptides may be delayed or prolonged by the cheese matrix, and, finally, depending on the cheese's salt content or the presence of biogenic amines, adverse effects may even occur.

\section{REFERENCES}

[1] Addeo F., Chianese L., Sacchi R., Musso S.S., Ferranti P., Malorni A., Characterization of the oligopeptides of Parmigiano-Reggiano cheese soluble in $120 \mathrm{~g}$ trichloroacetic acid, J. Dairy Res. 61 (1994) 365-374.

[2] Ai L.Z., Guo B.H., Zhang H., Wu Z.J., Chen W., Wang Y.Y., Tang J.A., Isolation and antihypertensive effect of exopolysaccharides from Lactobacillus casei LC2W, Milchwissenschaft-Milk Sci. Int. 63 (2008) 3-6.

[3] Aihara K., Kajimoto O., Hirata H., Takahashi R., Nakamura Y., Effect of powdered fermented milk with Lactobacillus 
helveticus on subjects with high-normal blood pressure or mild hypertension, J. Am. Coll. Nutr. 24 (2005) 257-265.

[4] Apostolidis E., Kwon Y.I., Shetty K., Inhibitory potential of herb, fruit, and fungal-enriched cheese against key enzymes linked to type 2 diabetes and hypertension, Innovat. Food Sci. Emerg. Technol. 8 (2007) 46-54.

[5] Appel L.J., Moore T.J., Obarzanek E., Vollmer W.M., Svetkey L.P., Sacks F.M., Bray G.A., Vogt T.M., Cutler J.A., Windhauser M.M., Lin P.H., Karanja N., A clinical trial of the effects of dietary patterns on blood pressure, N. Engl. J. Med. 336 (1997) 1117-1124.

[6] Ashar M.N., Chand R., Antihypertensive peptides purified from milks fermented with Lactobacillus delbrueckii ssp. bulgaricus, Milchwissenschaft-Milk Sci. Int. 59 (2004) 14-17.

[7] Bachmann H.P., Bütikofer U., Badertscher R., Dalla Torre M., Lavanchy P., Bühler-Moor U., Nick B., Jimeno J., Warmke R., Grosch W., Sieber R., Bosset J.O., Reifungsverlauf von in Folien verpacktem Emmentaler Käse mit und ohne Zusatz von Lactobacillus casei subsp. casei. I. Mikrobiologische, chemische, rheologische und sensorische Untersuchungen, Lebensm.-Wiss. Technol. 30 (1997) 417-428.

[8] Bachmann H.P., Bütikofer U., Meyer J., Prediction of flavour and texture development in Swiss-type cheeses, Food Sci. Technol.-Lebensm.-Wiss. Technol. 32 (1999) 284-289.

[9] Bachmann H.P., Bütikofer U., Sieber R., Über das Vorkommen von bioaktiven Peptiden in Käse, Mitt. Lebensmittelunters. Hyg. 94 (2003) 136-154.

[10] Bernard B.K., Studies of the toxicological potential of tripeptides (L-valyl-L-prolyl-Lproline and L-isoleucyl-L-prolyl-L-proline): I. Executive summary, Int. J. Toxicol. 24 (2005) 1-3.

[11] Bernard B.K., Nakamura Y., Aihara K., Mennear J.H., Studies of the toxicological potential of tripeptides (L-valyl-L-prolyl-Lproline and L-isoleucyl-L-prolyl-L-proline): IX. Evaluation of the mutagenic potential of synthesized L-valyl-L-prolylL-proline in the Salmonella-Escherichia coli/microsome, incorporation assay, Int. J. Toxicol. 24 (2005) 107-113.
[12] Bernard B.K., Nakamura Y., Bando I., Mennear J.H., Studies of the toxicological potential of tripeptides (L-valyl-L-prolyl-Lproline and L-isoleucyl-L-prolyl-L-proline): II. Introduction, Int. J. Toxicol. 24 (2005) 5-11.

[13] Boelsma E., Kloek J., Lactotripeptides and antihypertensive effects: a critical review, Br. J. Nutr. 101 (2009) 776-786.

[14] Bütikofer U., Baumann E., Sieber R., Bosset J.O., Ripening of Emmental cheese wrapped in foil with and without addition of Lactobacillus casei subsp. casei. IV. HPLC separation of water soluble peptides, Food Sci. Technol.-Lebensm.-Wiss. Technol. 31 (1998) 297-301.

[15] Bütikofer U., Meyer J., Sieber R., Walther B., Wechsler D., Occurrence of the angiotensin-converting enzyme-inhibiting tripeptides Val-Pro-Pro and Ile-Pro-Pro in different cheese varieties of Swiss origin, J. Dairy Sci. 91 (2008) 29-38.

[16] Bütikofer U., Meyer J., Sieber R., Wechsler D., Quantification of the angiotensin-converting enzmye-inhibiting tripeptides ValPro-Pro and Ile-Pro-Pro in hard, semi-hard and soft cheeses, Int. Dairy J. 17 (2007) 968-975.

[17] Cadée J.A., Chang C.Y., Chen C.W., Huang C.N., Chen S.L., Wang C.K., Bovine casein hydrolysate (C12 peptide) reduces blood pressure in prehypertensive subjects, Am. J. Hypertens. 20 (2007) 1-5.

[18] Cheung H.S., Cushman D.W., Inhibition of homogeneous angiotensin-converting enzyme of rabbit lung by synthetic venom peptides of Bothrops jararaca, Biochim. Biophys. ActaEnzymol. 293 (1973) 451-463.

[19] Christensen J.E., Dudley E.G., Pederson J.A., Steele J.L., Peptidases and amino acid catabolism in lactic acid bacteria, Antonie van Leeuwenhoek, Int. J. Gen. Molec. Microbiol. 76 (1999) 217-246.

[20] Curtis J.M., Dennis D., Waddell D.S., MacGillivray T., Ewart H.S., Determination of angiotensin-converting enzyme inhibitory peptide Leu-Lys-Pro-Asn-Met (LKPNM) in bonito muscle hydrolysates by LC-MS/MS, J. Agric. Food Chem. 50 (2002) 3919-3925.

[21] Cushman D.W., Cheung H.S., Spectrophotometric assay and properties of the angiotensin-converting enzyme of rabbit lung, Biochem. Pharmacol. 20 (1970) 16371648 . 
[22] Dent M.P., O'Hagan S., Braun W.H., Schaetti P., Marburger A., Vogel O., A 90-day subchronic toxicity study and reproductive toxicity studies on ACE-inhibiting lactotripeptide, Food Chem. Toxicol. 45 (2007) 1468-1477.

[23] Engberink M.F., Schouten E.G., Kok F.J., van Mierlo L.A.J., Brouwer I.A., Geleijnse J.M., Lactotripeptides show no effect on human blood pressure. Results from a double-blind randomized controlled trial, Hypertension 51 (2008) 399-405.

[24] FitzGerald R.J., Murray B.A., Bioactive peptides and lactic fermentations, Int. J. Dairy Technol. 59 (2006) 118-125.

[25] FitzGerald R.J., Murray B.A., Walsh D.J., Hypotensive peptides from milk proteins, J. Nutr. 134 (2004) 980S-988S.

[26] Foltz M., Meynen E.E., Bianco V., van Platerink C., Koning T.M.M.G., Kloek J., Angiotensin converting enzyme inhibitory peptides from a lactotripeptide-enriched milk beverage are absorbed intact into the circulation, J. Nutr. 137 (2007) 953-958.

[27] Fuglsang A., Nilsson D., Nyborg N.C.B., Cardiovascular effects of fermented milk containing angiotensin-converting enzyme inhibitors evaluated in permanently catheterized, spontaneously hypertensive rats, Appl. Environ. Microbiol. 68 (2002) 35663569.

[28] Gagnaire V., Mollé D., Herrouin M., Léonil J., Peptides identified during Emmental cheese ripening: origin and proteolytic systems involved, J. Agric. Food Chem. 49 (2001) 4402-4413.

[29] Gavras H., Brunner H.R., Role of angiotensin and its inhibition in hypertension, ischemic heart disease, and heart failure, Hypertension 37 (2001) 342-345.

[30] Gobbetti M., Ferranti P., Smacchi E., Goffredi F., Addeo F., Production of angiotensin-Iconverting-enzyme-inhibitory peptides in fermented milks started by Lactobacillus delbrueckii subsp. bulgaricus SS1 and Lactococcus lactis subsp. cremoris FT4, Appl. Environ. Microbiol. 66 (2000) 3898-3904.

[31] Gómez-Ruiz J.Á., Ramos M., Recio I., Angiotensin-converting enzyme-inhibitory peptides in Manchego cheeses manufactured with different starter cultures, Int. Dairy J. 12 (2002) 697-706.

[32] Gómez-Ruiz J.Á., Ramos M., Recio I., Angiotensin converting enzyme-inhibitory activity of peptides isolated from
Manchego cheese. Stability under simulated gastrointestinal digestion, Int. Dairy J. 14 (2004) 1075-1080.

[33] Gómez-Ruiz J.Á., Ramos M., Recio I., Identification and formation of angiotensinconverting enzyme-inhibitory peptides in Manchego cheese by high-performance liquid chromatography-tandem mass spectrometry, J. Chromatogr. A 1054 (2004) 269-277.

[34] Gómez-Ruiz J.Á., Taborda G., Amigo L., Ramos M., Molina E., Sensory and mass spectrometric analysis of the peptidic fraction lower than one thousand daltons in Manchego cheese, J. Dairy Sci. 90 (2007) 4966-4973.

[35] Gómez-Ruiz J.Á., Taborda G., Amigo L., Recio I., Ramos M., Identification of ACEinhibitory peptides in different Spanish cheeses by tandem mass spectrometry, Eur. Food Res. Technol. 223 (2006) 595-601..5

[36] Haque E., Chand R., Antihypertensive and antimicrobial bioactive peptides from milk proteins, Eur. Food Res. Technol. 227 (2008) 7-15.

[37] Hata Y., Yamamoto M., Ohni M., Nakajima K., Nakamura Y., Takano T., A placebocontrolled study of the effect of sour milk on blood pressure in hypertensive subjects, Am. J. Clin. Nutr. 64 (1996) 767-771.

[38] Hernández-Ledesma B., Amigo L., Ramos M., Recio I., Angiotensin converting enzyme inhibitory activity in commercial fermented products, Formation of peptides under simulated gastrointestinal digestion, J. Agric. Food Chem. 52 (2004) 1504-1510.

[39] Inoue K., Shirai T., Ochiai H., Kasao M., Hayakawa K., Kimura M., Sansawa H., Blood-pressure-lowering effect of a novel fermented milk containing $\gamma$-aminobutyric acid (GABA) in mild hypertensives, Eur. J. Clin. Nutr. 57 (2003) 490-495.

[40] Jang A., Lee M., Purification and identification of angiotensin converting enzyme inhibitory peptides from beef hydrolysates, Meat Sci. 69 (2005) 653-661.

[41] Jauhiainen T., Blood pressure lowering effects of Lactobacillus helveticus fermented milk containing bioactive peptides Ile-Pro-Pro and Val-Pro-Pro: mechanistic, kinetic and clinical studies, Diss. University Helsinki, 2007, pp. 1-100.

[42] Jauhiainen T., Vapaatalo H., Poussa T., Kyrönpalo S., Rasmussen M., Korpela R., 
Lactobacillus helveticus fermented milk lowers blood pressure in hypertensive subjects in 24-h ambulatory blood pressure measurement, Am. J. Hypertens. 18 (2005) 1600-1605.

[43] Jauhiainen T., Wuolle K., Vapaatalo H., Kerojoki O., Nurmela K., Lowrie C., Korpela R., Oral absorption, tissue distribution and excretion of a radiolabelled analog of a milk-derived antihypertensive peptide, Ile-Pro-Pro, in rats, Int. Dairy J. 17 (2007) 1216-1223.

[44] Kajimoto O., Aihara K., Hirata H., Takahashi R., Nakamura Y., Safety evaluation of excessive intake of the tablet containing "Lactotripeptides (VPP, IPP)" on healthy volunteers, J. Nutr. Food 4 (2001) 37-46.

[45] Kamath V., Niketh S., Chandrashekar A., Rajini P.S., Chymotryptic hydrolysates of $\alpha$-kafirin, the storage protein of sorghum (Sorghum bicolor) exhibited angiotensin converting enzyme inhibitory activity, Food Chem. 100 (2007) 306-311.

[46] Katayama K., Anggraeni H.E., Mori T., Ahhmed A.M., Kawahara S., Sugiyama M., Nakayama T., Maruyama M., Muguruma M., Porcine skeletal muscle troponin is a good source of peptides with angiotensin-I converting enzyme inhibitory activity and antihypertensive effects in spontaneously hypertensive rats, J. Agric. Food Chem. 56 (2008) 355-360.

[47] Katayama K., Jamhari, Mori T., Kawahara S., Miake K., Kodama Y., Sugiyama M., Kawamura Y., Nakayama T., Maruyama M., Muguruma M., Angiotensin-I converting enzyme inhibitory peptide derived from porcine skeletal muscle myosin and its antihypertensive activity in spontaneously hypertensive rats, J. Food Sci. 72 (2007) S702-S706.

[48] Kenny O., FitzGerald R.J., O’Cuinn G., Beresford T., Jordan K., Growth phase and growth medium effects on the peptidase activities of Lactobacillus helveticus, Int. Dairy J. 13 (2003) 509-516.

[49] Kilpi E.E.R., Kahala M.M., Steele J.L., Pihlanto A.M., Joutsjoki V.V., Angiotensin I-converting enzyme inhibitory activity in milk fermented by wild-type and peptidasedeletion derivatives of Lactobacillus helveticus CNRZ32, Int. Dairy J. 17 (2007) 976-984.
[50] Korhonen H., Milk-derived bioactive peptides: From science to applications, J. Funct. Foods 1 (2009) 177-187.

[51] Kurosaki T., Maeno M., Mennear J.H., Bernard B.K., Studies of the toxicological potential of tripeptides (L-valyl-L-prolylL-proline and L-isoleucyl-L-prolyl-L-proline): VI. Effects of Lactobacillus helveticus-fermented milk powder on fertility and reproductive performance of rats, Int. J. Toxicol. 24 (2005) 61-89.

[52] Leclerc P.L., Gauthier S.F., Bachelard H., Santure M., Roy D., Antihypertensive activity of casein-enriched milk fermented by Lactobacillus helveticus, Int. Dairy J. 12 (2002) 995-1004.

[53] Li G.H., Le G.W., Shi Y.H., Shrestha S., Angiotensin I-converting enzyme inhibitory peptides derived from food proteins and their physiological and pharmacological effects, Nutr. Res. 24 (2004) 469-486.

[54] Lo W.M.Y., Li-Chan E.C.Y., Angiotensin I converting enzyme inhibitory peptides from in vitro pepsin-pancreatin digestion of soy protein, J. Agric. Food Chem. 53 (2005) 3369-3376.

[55] Maeno M., Mizuno S., Mennear J.H., Bernard B.K., Studies of the toxicological potential of tripeptides (L-valyl-L-prolyl-Lproline and L-isoleucyl-L-prolyl-L-proline): VIII. Assessment of cytotoxicity and clastogenicity of tripeptides-containing casein hydrolysate and Lactobacillus helveticus-fermented milk powders in Chinese hamster lung cells, Int. J. Toxicol. 24 (2005) 97-105.

[56] Maeno M., Nakamura Y., Mennear J.H., Bernard B.K., Studies of the toxicological potential of tripeptides (L-valyl-L-prolyl-Lproline and L-isoleucyl-L-prolyl-L-proline): III. Single- and/or repeated-dose toxicity of tripeptides-containing Lactobacillus helveticus-fermented milk powder and casein hydrolysate in rats, Int. J. Toxicol. 24 (2005) 13-23.

[57] Maeno M., Yamamoto N., Takano T., Identification of an antihypertensive peptide from casein hydrolysate produced by a proteinase from Lactobacillus helveticus CP790, J. Dairy Sci. 79 (1996) 1316-1321.

[58] Mäkinen S., Kelloniemi J., Pihlanto A., Mäkinen K., Korhonen H., Hopia A., Valkonen J.P.T., Inhibition of angiotensin converting enzyme I caused by autolysis of potato proteins by enzymatic activities confined to different parts of the potato 
tuber, J. Agric. Food Chem. 56 (2008) 9875-9883.

[59] Masuda O., Nakamura Y., Takano T., Antihypertensive peptides are present in aorta after oral administration of sour milk containing these peptides to spontaneously hypertensive rats, J. Nutr. 126 (1996) 3063-3068

[60] Matsufuji H., Matsui T., Seki E., Osajima K., Nakashima M., Osajima Y., Angiotensin I-converting enzyme inhibitory peptides in an alkaline protease hydrolyzate derived from sardine muscle, Biosci. Biotechnol. Biochem. 58 (1994) 2244-2245.

[61] Matsui T., Matsufuji H., Seki E., Osajima K., Nakashima M., Osajima Y., Inhibition of angiotensin I-converting enzyme by Bacillus licheniformis alkaline protease hydrolyzates derived from sardine muscle, Biosci. Biotechnol. Biochem. 57 (1993) 922-925.

[62] Matsui T., Yukiyoshi A., Doi S., Sugimoto H., Yamada H., Matsumoto K., Gastrointestinal enzyme production of bioactive peptides from royal jelly protein, their antihypertensive ability in SHR, J. Nutr. Biochem. 13 (2002) 80-86.

[63] McCarron D.A., Reusser M.E., Finding consensus in the dietary calcium-blood pressure debate, J. Am. Coll. Nutr. 18 (1999) 398S-405S.

[64] Meisel H., Goepfert A., Günther S., ACEinhibitory activities in milk products, Milchwissenschaft-Milk Sci. Int. 52 (1997) 307-311.

[65] Meisel H., Walsh D.J., Murray B., FitzGerald R.J., ACE inhibiting peptides, in: Mine Y., Shahidi S. (Eds.), Nutraceutical Proteins and Peptides in Health and Disease, CRC Press, New York, USA, 2006, pp. 269-315.

[66] Meyer J., Bütikofer U., Walther B., Wechsler D., Sieber R., Changes in angiotensin-converting enzyme inhibition and concentrations of the tripeptides Val-Pro-Pro and Ile-Pro-Pro during ripening of different Swiss cheese varieties, J. Dairy Sci. 92 (2009) 826-836.

[67] Miguel M., Aleixandre A., Antihypertensive peptides derived from egg proteins, J. Nutr. 136 (2006) 1457-1460.

[68] Miguel M., Manso M., Aleixandre A., Alonso M.J., Salaices M., López-Fandiño R., Vascular effects, angiotensin I-converting enzyme (ACE)-inhibitory activity, and antihypertensive properties of peptides derived from egg white, J. Agric. Food Chem. 55 (2007) 10615-10621.

[69] Minervini F., Algaron F., Rizzello C.G., Fox P.F., Monnet V., Gobbetti A., Angiotensin I-converting-enzyme-inhibitory and antibacterial peptides from Lactobacillus helveticus PR4 proteinase-hydrolyzed caseins of milk from six species, Appl. Environ. Microbiol. 69 (2003) 5297-5305.

[70] Mito K., Fujii M., Kuwahara M., Matsumura N., Shimizu T., Sugano S., Karaki H., Antihypertensive effect of angiotensin I-converting enzyme inhibitory peptides derived from hemoglobin, Eur. J. Pharmacol. 304 (1996) 93-98.

[71] Miyoshi S., Kaneko T., Yoshizawa Y., Fukui F., Tanaka H., Maruyama S., Hypotensive activity of enzymatic $\alpha$-zein hydrolysate, Agric. Biol. Chem. 55 (1991) 1407-1408.

[72] Mizuno S., Matsuura K., Gotou T., Nishimura S., Kajimoto O., Yabune M., Kajimoto Y., Yamamoto N., Antihypertensive effect of casein hydrolysate in a placebo-controlled study in subjects with high-normal blood pressure and mild hypertension, Br. J. Nutr. 94 (2005) 84-91.

[73] Mizuno S., Mennear J.H., Matsuura K., Bernard B.K., Studies of the toxicological potential of tripeptides (L-valyl-L-prolyl-Lproline, L-isoleucyl-L-prolyl-L-proline): V. A 13-week toxicity study of tripeptidescontaining casein hydrolysate in male and female rats, Int. J. Toxicol. 24 (2005) 41-59.

[74] Mizushima S., Ohshige K., Watanabe J., Kimura M., Kadowaki T., Nakamura Y., Tochikubo O., Ueshima H., Randomized controlled trial of sour milk on blood pressure in borderline hypertensive men, Am. J. Hypertens. 17 (2004) 701-706.

[75] Möller N.P., Scholz-Ahrens K.E., Roos N., Schrezenmeir J., Bioactive peptides and proteins from foods: indication for health effects, Eur. J. Nutr. 47 (2008) 171-182.

[76] Muguerza B., Ramos M., Sanchez E., Manso M.A., Miguel M., Aleixandre A., Delgado M.A., Recio I., Antihypertensive activity of milk fermented by Enterococcus faecalis strains isolated from raw milk, Int. Dairy J. 16 (2006) 61-69.

[77] Nakamura Y., Bando I., Mennear J.H., Bernard B.K., Studies of the toxicological potential of tripeptides (L-valyl-L-prolyl-Lproline and L-isoleucyl-L-prolyl-L-proline): IV. Assessment of the repeated-dose 
toxicological potential of synthesized L-valyl-L-prolyl-L-proline in male and female rats and dogs, Int. J. Toxicol. 24 (2005) 25-39.

[78] Nakamura Y., Takano T., Angiotensin converting enzyme inhibitor and method for preparing same, US Patent 5449661, 1995.

[79] Nakamura Y., Yamamoto N., Sakai K., Okubo A., Yamazaki S., Takano T., Purification and characterization of angiotensin I-converting enzyme inhibitors from sour milk, J. Dairy Sci. 78 (1995) 777-783.

[80] Nakamura Y., Yamamoto N., Sakai K., Takano T., Antihypertensive effect of sour milk and peptides isolated from it that are inhibitors to angiotensin I-converting enzyme, J. Dairy Sci. 78 (1995) 12531257.

[81] Nakano D., Ogura K., Miyakoshi M., Ishii F., Kawanishi H., Kurumazuka D., Kwak C.J., Ikemura K., Takaoka M., Moriguchi S., Iino T., Kusumoto A., Asami S., Shibata H., Kiso Y., Matsumura Y., Antihypertensive effect of angiotensin I-converting enzyme inhibitory peptides from a sesame protein hydrolysate in spontaneously hypertensive rats, Biosci. Biotechnol. Biochem. 70 (2006) 1118-1126.

[82] Nielsen M.S., Martinussen T., Flambard B., Sørensen K.I., Otte J., Peptide profiles and angiotensin-I-converting enzyme inhibitory activity of fermented milk products: effect of bacterial strain, fermentation $\mathrm{pH}$, and storage time, Int. Dairy J. 19 (2009) 155-165.

[83] Nussberger J., Blutdrucksenkende Tripeptide aus der Milch, Ther. Umsch. 64 (2007) 177-179.

[84] Ohsawa K., Satsu H., Ohki K., Enjoh M., Takano T., Shimizu M., Producibility and digestibility of antihypertensive $\beta$-casein tripeptides, Val-Pro-Pro and Ile-Pro-Pro, in the gastrointestinal tract: analyses using an in vitro model of mammalian gastrointestinal digestion, J. Agric. Food Chem. 56 (2008) 854-858.

[85] Okamoto A., Hanagata H., Matsumoto E., Kawamura Y., Koizumi Y., Yanagida F., Angiotensin-converting enzyme inhibitory activities of various fermented foods, Biosci. Biotechnol. Biochem. 59 (1995) 1147-1149.

[86] Ong L., Henriksson A., Shah N.P., Angiotensin converting enzyme-inhibitory activity in Cheddar cheeses made with the addition of probiotic Lactobacillus casei sp., Lait 87 (2007) 149-165.
[87] Ong L., Shah N.P., Influence of probiotic Lactobacillus acidophilus and L. helveticus on proteolysis, organic acid profiles, and ACE-inhibitory activity of Cheddar cheeses ripened at 4,8 , and $12{ }^{\circ} \mathrm{C}$, J. Food Sci. 73 (2008) M111-M120.

[88] Ong L., Shah N.P., Release and identification of angiotensin-converting enzymeinhibitory peptides as influenced by ripening temperatures and probiotic adjuncts in Cheddar cheeses, LWT - Food Sci. Technol. 41 (2008) 1555-1566.

[89] Pan D., Luo Y., Tanokura M., Antihypertensive peptides from skimmed milk hydrolysate digested by cell-free extract of Lactobacillus helveticus JCM1004, Food Chem. 91 (2005) 123-129.

[90] Parrot S., Degraeve P., Curia C., MartialGros A., In vitro study on digestion of peptides in Emmental cheese: analytical evaluation and influence on angiotensin I converting enzyme inhibitory peptides, Nahrung-Food 47 (2003) 87-94.

[91] Pihlanto A., Akkanen S., Korhonen H.J., ACE-inhibitory and antioxidant properties of potato (Solanum tuberosum), Food Chem. 109 (2008) 104-112.

[92] Ponstein-Simarro Doorten A.Y., vd Wiel J.A.G., Jonker D., Safety evaluation of an IPP tripeptide-containing milk protein hydrolysate, Food Chem. Toxicol. 47 (2009) 55-61.

[93] Pozo-Bayón M.A., Alcaide J.M., Polo M.C., Pueyo E., Angiotensin I-converting enzyme inhibitory compounds in white and red wines, Food Chem. 100 (2007) 43-47.

[94] Pripp A.H., Effect of peptides derived from food proteins on blood pressure: a metaanalysis of randomized controlled trials, Food Nutr. Res. 52 (2008) DOI: 10.3402/fnr. v52i0.1641. http://www.ncbi.nlm.nih.gov/ pmc/articles/PMC2596738/pdf/FNR-521641.pdf.

[95] Pripp A.H., Sørensen R., Stepaniak L., Sørhaug T., Relationship between proteolysis and angiotensin-I-converting enzyme inhibition in different cheeses, LWT - Food Sci. Technol. 39 (2006) 677-683.

[96] Prospective Studies Collaboration, Agespecific relevance of usual blood pressure to vascular mortality: a meta-analysis of individual data for one million adults in 61 prospective studies, Lancet 360 (2002) 1903-1913. 
[97] Quirós A., Chichón R., Recio I., López-Fandiño R., The use of high hydrostatic pressure to promote the proteolysis and release of bioactive peptides from ovalbumin, Food Chem. 104 (2007) 1734-1739.

[98] Quist E.E., Phillips R.D., Saalia F.K., Angiotensin converting enzyme inhibitory activity of proteolytic digests of peanut (Arachis hypogaea L.) flour, LWT - Food Sci. Technol. 42 (2009) 694-699.

[99] Rank T.C., Grappin R., Olson N.F., Secondary proteolysis of cheese during ripening. A review, J. Dairy Sci. 68 (1985) 801805.

[100] Robert M.C., Razaname A., Mutter M., Juillerat M.A., Identification of angiotensin-I-converting enzyme inhibitory peptides derived from sodium caseinate hydrolysates produced by Lactobacillus helveticus NCC 2765, J. Agric. Food Chem. 52 (2004) 6923-6931.

[101] Rufián-Henares J.A., Morales F.J., Angiotensin-I converting enzyme inhibitory activity of coffee melanoidins, J. Agric. Food Chem. 55 (2007) 1480-1485.

[102] Ryhänen E.L., Pihlanto-Leppälä A., Pahkala E., A new type of ripened, lowfat cheese with bioactive properties, Int. Dairy J. 11 (2001) 441-447.

[103] Saiga A., Iwai K., Hayakawa T., Takahata Y., Kitamura S., Nishimura T., Morimatsu F., Angiotensin I-converting enzyme-inhibitory peptides obtained from chicken collagen hydrolysate, J. Agric. Food Chem. 56 (2008) 9586-9591.

[104] Saiga A., Okumura T., Makihara T., Katsuda S.I., Morimatsu F., Nishimura T., Action mechanism of an angiotensin I-converting enzyme inhibitory peptide derived from chicken breast muscle, J. Agric. Food Chem. 54 (2006) 942-945.

[105] Saito T., Nakamura T., Kitazawa H., Kawai Y., Itoh T., Isolation and structural analysis of antihypertensive peptides that exist naturally in Gouda cheese, J. Dairy Sci. 83 (2000) 1434-1440.

[106] Sano J., Ohki K., Higuchi T., Aihara K., Mizuno S., Kajimoto O., Nakagawa S., Kajimoto Y., Nakamura Y., Safety evaluation of excessive intake of drink containing "lactotripeptides (VPP, IPP)" in subjects with normal blood pressure to mild hypertension, J. Nutr. Food 7 (2005) 17-30.

[107] Savijoki K., Palva A., Purification and molecular characterization of a tripeptidase
(PepT) from Lactobacillus helveticus, Appl. Environ. Microbiol. 66 (2000) 794-800.

[108] Schär H., Glättli H., Moor U., Nick B., Sieber R., Steiger G., Untersuchungen über den Reifungsverlauf von qualitativ gutem Walliser Raclettekäse, Schweiz. Milchwirt. Forsch. 21 (1992) 52-57.

[109] Seppo L., Jauhiainen T., Poussa T., Korpela R., A fermented milk high in bioactive peptides has a blood pressure-lowering effect in hypertensive subjects, Am. J. Clin. Nutr. 77 (2003) 326-330.

[110] Seppo L., Kerojoki O., Suomalainen T., Korpela R., The effect of a Lactobacillus helveticus LBK-16 $\mathrm{H}$ fermented milk on hypertension - a pilot study on humans, Milchwissenschaft-Milk Sci. Int. 57 (2002) 124-127.

[111] Shalaby S.M., Zakora M., Otte J., Performance of two commonly used angiotensinconverting enzyme inhibition assays using FA-PGG and HHL as substrates, J. Dairy Res. 73 (2006) 178-186.

[112] Sheih I.-C., Fang T.J., Wu T.-K., Isolation and characterisation of a novel angiotensin I-converting enzyme (ACE) inhibitory peptide from the algae protein waste, Food Chem. 115 (2009) 279-284

[113] Shuangquan, Tsuda H., Myamoto T., Angiotensin I-converting enzyme inhibitory peptides in skim milk fermented with Lactobacillus helveticus 130B4 from camel milk in Inner Mongolia, China, J. Sci. Food Agric. 88 (2008) 2688-2692.

[114] Sieber R., Käse - ein wertvolles Lebensmittel in der menschlichen Ernährung, Mitt. Lebensm. Hyg. 96 (2005) 141-170.

[115] Silva S.V., Pihlanto A., Malcata F.X., Bioactive peptides in ovine and caprine cheeselike systems prepared with proteases from Cynara cardunculus, J. Dairy Sci. 89 (2006) 3336-3344.

[116] Sipola M., Finckenberg P., Korpela R., Vapaatalo H., Nurminen M.L., Effect of long-term intake of milk products on blood pressure in hypertensive rats, J. Dairy Res. 69 (2002) 103-111.

[117] Sipola M., Finckenberg P., Santisteban J., Korpela R., Vapaatalo H., Nurminen M.L., Long-term intake of milk peptides attenuates development of hypertension in spontaneously hypertensive rats, J. Physiol. Pharmacol. 52 (2001) 745-754.

[118] Smacchi E., Gobbetti M., Peptides from several Italian cheeses inhibitory to 
proteolytic enzymes of lactic acid bacteria, Pseudomonas fluorescens ATCC 948 and to the angiotensin I-converting enzyme, Enzyme Microb. Technol. 22 (1998) 687694.

[119] Sollberger H., Glättli H., Nick B., Rüegg M., Sieber R., Steiger G., Untersuchungen über den Reifungsverlauf guter SbrinzKäse, Schweiz. Milchwirt. Forschung 20 (1991) 63-69.

[120] Steffen C., Rentsch F., Nick B., Steiger G., Sieber R., Glättli H., Eberhard P., Reifungsverlauf in qualitativ gutem Gruyère, Landwirt. Schweiz 5 (1992) 209-215.

[121] Steffen C., Schär H., Eberhard P., Glättli H., Nick B., Rentsch F., Steiger G., Sieber R., Untersuchungen über den Reifungsverlauf von qualitativ gutem Käse: Appenzeller, Schweiz. Milchwirt. Forsch. 21 (1993) 39-45.

[122] Steffen C., Schär H., Eberhard P., Glättli H., Nick B., Rentsch F., Steiger G., Sieber R., Untersuchungen über den Reifungsverlauf von qualitativ gutem Käse: Tilsiter aus Rohmilch, Schweiz. Milchwirt. Forsch. 21 (1993) 46-51.

[123] Stepaniak L., Jedrychowski L., Wróblewska B., Sørhaug T., Immunoreactivity and inhibition of angiotensin-I converting enzyme and lactococcal oligopeptidase by peptides from cheese, Ital. J. Food Sci. 13 (2001) 373381.

[124] Taubert D., Roesen R., Schömig E., Effect of cocoa and tea intake on blood pressure. A meta-analysis, Arch. Int. Med. 167 (2007) 626-634.

[125] Tonouchi H., Suzuki M., Uchida M., Oda M., Antihypertensive effect of an angiotensin converting enzyme inhibitory peptide from enzyme modified cheese, J. Dairy Res. 75 (2008) 284-290.

[126] Tossavainen O., Suomalainen T., Sahlstein J., Mäyrä-Mäkinen A., Verfahren zur Herstellung eines Produktes, welches gegen Bluthochdruck gerichtete Tripeptide enthält, Dt. Patent DE $600 \quad 10742 \quad$ T2 (2005).

[127] Townsend R.R., McFadden C.B., Ford V., Cadée J.A., A randomized, double-blind, placebo-controlled trial of casein protein hydrolysate (C12 peptide) in human essential hypertension, Am. J. Hypertens. 17 (2004) 1056-1058.

[128] Tuomilehto J., Lindström J., Hyyrynen J., Korpela R., Karhunen M.L., Mikkola L.,
Jauhiainen T., Seppo L., Nissinen A., Effect of ingesting sour milk fermented using Lactobacillus helveticus bacteria producing tripeptides on blood pressure in subjects with mild hypertension, J. Hum. Hypertens. 18 (2004) 795-802.

[129] van der Pijl P.C., Kies A.K., Ten Have G.A.M., Duchateau G.S.M.J.E., Deutz N.E.P., Pharmacokinetics of proline-rich tripeptides in the pig, Peptides 29 (2008) 2196-2202.

[130] van der Zander K., Bots M.L., Bak A.A.A., Koning M.M.G., de Leeuw P.W., Enzymatically hydrolyzed lactotripeptides do not lower blood pressure in mildly hypertensive subjects, Am. J. Clin. Nutr. 88 (2008) 1697-1702.

[131] van Mierlo L.A.J., Koning M.M.G., van der Zander K., Draijer R., Lactotripeptides do not lower ambulatory blood pressure in untreated whites: results from 2 controlled multicenter crossover studies, Am. J. Clin. Nutr. 89 (2009) 617-623.

[132] van Platerink C.J., Janssen H.G., Horsten R., Haverkamp J., Quantification of ACE inhibiting peptides in human plasma using high performance liquid chromatographymass spectrometry, J. Chromatogr. B 830 (2006) 151-157.

[133] Vermeirssen V., Van Camp J., Verstraete W., Optimisation and validation of an angiotensin-converting enzyme inhibition assay for the screening of bioactive peptides, J. Biochem. Biophys. Methods 51 (2002) 75-87.

[134] Wang J., Hu J., Cui J., Bai X., Du Y., Miyaguchi Y., Lin B., Purification and identification of a ACE inhibitory peptide from oyster proteins hydrolysate and the antihypertensive effect of hydrolysate in spontaneously hypertensive rats, Food Chem. 111 (2008) 302-308.

[135] Webb A.J., Patel N., Loukogeorgakis S., Okorie M., Aboud Z., Misra S., Rashid R., Miall P., Deanfield J., Benjamin N., MacAllister R., Hobbs A.J., Ahluwalia A., Acute blood pressure lowering, vasoprotective, and antiplatelet properties of dietary nitrate via bioconversion to nitrite, Hypertension 51 (2008) 784-790.

[136] Xu J.Y., Qin L.Q., Wang P.Y., Li W., Chang C., Effect of milk tripeptides on blood pressure: a meta-analysis of randomized controlled trials, Nutrition 24 (2008) 933-940.

[137] Yamamoto N., Akino A., Takano T., Antihypertensive effect of the peptides derived 
from casein by an extracellular proteinase from Lactobacillus helveticus CP790, J. Dairy Sci. 77 (1994) 917-922.

[138] Yamamoto N., Akino A., Takano T., Antihypertensive effects of different kinds of fermented milk in spontaneously hypertensive rats, Biosci. Biotechnol. Biochem. 58 (1994) 776-778.

[139] Yamamoto N., Maeno M., Takano T., Purification and characterization of an antihypertensive peptide from a yogurt-like product fermented by Lactobacillus helveticus CPN4, J. Dairy Sci. 82 (1999) 13881393.

[140] Yang Y., Tao G., Liu P., Liu J., Peptide with angiotensin I-converting enzyme inhibitory activity from hydrolyzed corn gluten meal, J. Agric. Food Chem. 55 (2007) 78917895.

[141] Yano S., Suzuki K., Funatsu G., Isolation from $\alpha$-zein of thermolysin peptides with angiotensin I-converting enzyme inhibitory activity, Biosci. Biotechnol. Biochem. 60 (1996) 661-663.

\section{Appendix}

Abbreviation:

ACE angiotensin-converting enzyme

$\mathrm{CN}$ casein

DBP diastolic blood pressure

FAPGG furanacryloyl-phenylalanyl-glycylglycine

HHL hippuryl-histidyl-leucyl-OH

HPLC high-performance liquid chromatography

IPP isoleucyl-prolyl-proline

MS mass spectrometry

SBP systolic blood pressure

SHR spontaneously hypertensive rats

VPP valyl-prolyl-proline 